\title{
MENGELOLA ENERGI SPIRITUAL BAGI DAI: BELAJAR DARI NABI IBRAHIM
}

\author{
Ahmad Hidayat \\ STID Al-Hadid, Surabaya \\ ahmadhidayat@stidalhadid.ac.id
}

\author{
Dedy Pradesa \\ STID Al-Hadid, Surabaya \\ depra19312@gmail.com
}

\begin{abstract}
Abstrak: Energi spiritual adalah penggerak di balik semua kegiatan seseorang untuk menjalankan nilai yang dipegang teguh dan dengan tujuan di luar kepentingan pribadi, termasuk kegiatan menjalankan kewajiban berdakwah. Penting bagi dai, yaitu subjek atau pelaku dakwah, untuk memiliki metode manajemen energi spiritual yang baik, yaitu: (1) memiliki teknik meningkatkan energi spiritual, sehingga memiliki kapasitas yang tinggi; (2) kemampuan menggunakanya secara efisien, serta; (3) memiliki sistem pemulihannya. Lewat teladan Nabi Ibrahim sebagai dai, kita dapat menggali tiga teknik manajemen energi spiritual di atas. Pijakan teori yang digunakan adalah manajemen energi spiritual Jim Loehr dan Tony Schawartz. Metodologi studinya adalah studi pustaka. Hasil telah pustaka ini adalah: (1) Nabi Ibrahim secara terus menerus dan bertahap meningkatkan kapasitas energi spiritualnya, melalui menjalankan perintah berdakwah yang menantang rasa amannya; (2) Nabi Ibrahim tidak membenci dan sakit hati dengan penolakan misi dakwahnya, sebaliknya la terus menggunakan pendekatan ilmiah, tidak memaksa dan mendoakan keselamatan pada mereka yang menolak, sehingga energi spiritualnya tidak boros dikeluarkan untuk rasa kecewa atau frustasi karena ditolak umat; (3) Nabi Ibrahim melakukan jeda dan memanfaatkan energi spiritualnya dengan mengingat kebesaran, kasih sayang, keadilan Allah Swt. serta kewajiban dakwah yang bersifat mutlak, melakukan dakwah secara etis, ilmiah, dan tidak memaksa.

Kata kunci: manajemen energi spiritual, dai, Nabi Ibrahim, dakwah
\end{abstract}

DAI'S SPIRITUAL ENERGY MANAGEMENT: LEARNING FROM THE PROPHET IBRAHIM. Abstract: Spiritual energy is a driving force behind all of someone's activities to perform strongly held values, to reach non-self-interest goals, including $d a^{\prime}$ wah activities. It is essential for a dai, the one conducting da'wah, to have good spiritual energy management method, which are: (1) having techniques to improve spiritual energy so that it reaches high capacity; (2) abilities to use it efficiently; and; (3) having its renewal system. Learning from the Prophet Ibrahim as a dai, we can discover three techniques of spiritual energy management. It is based on Jim Loehr and Tony Schwartz's spiritual energy management. It uses literature study. It indicates : (1) the Prophet Ibrahim gradually expanded his spiritual energy capacity through conducting obligation of da'wah challenging his safety; (2) the Prophet Ibrahim did not hate and feel resentful by refusals on his da'wah mission. On the contrary, he continuously applied scientific approach, did not insist, and prayed for the safety of the ones refusing his da'wah. Therefore, his spiritual energy was not wastefully spent for disappointment or frustration; (3) The Prophet Ibrahim took a break and utilized his spiritual energy for remembering Allah's greatness, compassion, and justice. He also utilized to conduct da'wah ethically, scientifically and without coercion.

Keywords: spiritual energy management, dai, The Prophet Ibrahim, da'wah 


\section{Pendahuluan}

Studi ini, berangkat dari fenomena hambatan dan tantangan dakwah, khususnya dalam hal pengelolaan diri subjek dakwah terkait bagaimana mengoptimalkan energi yang dimiliki. Dakwah adalah proses peningkatan iman dalam diri manusia sesuai syariat Islam. ${ }^{1}$ Dalam proses peningkatan iman tersebut ada upaya untuk menyeru dan mengajak mitra dakwah pada kebaikan subjek dakwah. Dalam kegiatan dakwah tentu akan ada hambatan dan tantangan yang dihadapi. Hambatan dan tantangan tersebut bisa berasal dari faktor internal di antaranya dari aspek subjek dakwah, dan eksternal yaitu terkait keadaan mitra dakwah, masyarakat, maupun keadaankeadaan lingkungan lainnya. Studi dari Iskandar Al-Warisyi yang mengkaji jalan dakwah tujuh rasul Allah dalam memperbaiki masyarakat jahiliyah telah menunjukkan bagaimana tantangan dakwah itu senantiasa ada di setiap zaman. ${ }^{2}$

Maka, demikian pula dengan dakwah pada era modern saat ini, memiliki tantangan dan hambatan tersendiri. Tantangan tersebut di antaranya adalah yang bersifat kerawanankerawanan moral yang tersaji dalam berbagai bentuk hiburan maupun yang berdalih sebagai kegiatan seni dan kepariwisataan. Kerawanan moral yang dimaksud adalah terkait fenomenafenomena pornografi dan pornoaksi yang sangat mudah didapatkan dan dibagikan pada era kemajuan teknologi informasi dan

\footnotetext{
1 Moh. Ali Azis, Ilmu Dakwah: Edisi Revisi (Jakarta: Kencana, 2017), 19.

2 Iskandar Al-Warisyi, Dakwah Illahiah - Jalan Dakwah Tujuh Rasul Allah dalam Memperbaiki Masyarakat Jahiliyah (Surabaya: Yayasan Al-Kahfi, 2002), 276-81.

3 Khatib Pahlawan Kayo, Manajemen Dakwah dari Dakwah Konvensional menuju Dakwah Profesional (Jakarta: Amzah, 2007), 7-8.
}

komunikasi saat ini. Fenomena perjudian, kriminalitas, minuman keras, narkoba, dan sebagainya. ${ }^{3}$ Kerawanan-kerawanan moral tersebut sudah seperti dalam genggaman. Dengan bekal smartphone yang dimiliki, seseorang bisa menjelajah ke berbagai aplikasi media sosial dan mencari hiburanhiburan atau informasi yang bisa mengantarkan pada kerusakan moral. Dakwah pada era modern saat ini secara sosiologis akan berhadapan dengan tantangan pengaruh nilai-nilai dan budaya yang bercorak individualis dan materialistis. Hal tersebut, dapat disaksikan bagaimana sebagian masyarakat lebih mementingkan materi, menempatkan harta dunia di atas segalanya, bermegah-megahan sampai melenakan, materi dan kekayaan dijadikan sebagai cita-cita hidup yang terus dikejar sampai lupa terhadap tanggung jawab sosial dan kehidupan akhirat. ${ }^{4}$ Sehingga, tidak mudah untuk melakukan dakwah, dibutuhkan energi yang besar untuk bisa bertahan, menghadapi berbagai kesulitan, mampu untuk bangkit setelah jatuh, melakukan adaptasi untuk lebih baik, dan secara kontinu berkreasi untuk mencapai kemajuan.

Sementara, dari sisi dai selaku subjek dakwah terdapat kecenderungan hanya mengajak orang lain, tetapi lupa mengajak dan mengasah diri sendiri. Akibatnya, banyak dai yang hanya bisa memukau umat tetapi sesungguhnya gagal pada diri sendiri. ${ }^{5}$ Hal tersebut, mengindikasikan telah terjadi

\footnotetext{
4 Iskandar Al-Warisyi, Pengantar Silabus Dakwah Terprogram (Surabaya: Yayasan Al-Kahfi, 2012), 10.

${ }^{5}$ Meisil B. Wulur Meisil, "Problematika Dakwah di Indonesia," Jurnal Mimbar: Media Intelektual Muslim dan Bimbingan Rohani 2, no. 1 (2016): 105-21, doi:10.47435/mimbar.v2i1.274.
} 
krisis keteladanan figur seorang dai sebagai akibat dari dai yang tidak konsisten antara apa yang disampaikan dan dilaksanakan.

Krisis keteladanan dai tersebut diperparah dengan keberadaan dai pada era teknologi komunikasi dan informasi yang cenderung lebih mengedepankan unsur hiburan (entertainment) dalam kegiatan dakwahnya dan melahirkan apa yang disebut sebagai dai selebritis, yaitu para dai yang banyak tampil di televisi maupun media sosial. Mereka tampil di acara-acara dakwah yang mengkombinasikan dengan hiburan (dakwahtainment). Layaknya selebritis kehidupan pribadi dan keluarga mereka juga sering disorot media. Mereka juga tampil dengan busana modis, menjadi brand ambassador, ikut bermain sinteron dan film.

Ditinjau dari perspektif politik ekonomi media, kegiatan dakwahtainment tersebut tidak terlepas dari gejala komodifikasi. Yang salah satunya adalah komodifikasi tenaga kerja, yaitu dai selaku narasumber kegiatan dakwah. Narasumber yang dipilih selalu memiliki ciri khas menarik dari segi penampilan, unik, dan terpenting adalah bisa menghibur. Aspek isi ceramah bukan menjadi hal yang utama, malah menjadi bagian dari komodifikasi itu sendiri. ${ }^{6}$ Sebenarnya selama hal-hal tersebut tidak berlebihan dan dai betul-betul menguasai isi dakwah tidak masalah. Namun, dalam kenyataannya ada dai selebritis yang lebih mengutamakan kemasan dari pada isi materi dakwah. Bahkan, ada pula yang pernah tersandung kasus tarif dalam dakwah. Berdasarkan fenomena-fenomena di atas,

${ }^{6}$ Dedy Pradesa dan Yunda Presti Ardilla, "Komodifikasi dan efek eksternalitas program dakwahtainment islam itu indah," INTELEKSIA-Jurnal Pengembangan IImu Dakwah 02, no. 01 (2020): 81-106,
Efferi menyebut bahwa banyak para dai yang matanya 'tertutup' oleh godaan dunia, sehingga hidupnya selalu dipenuhi dengan kesulitan, dan kerepotan habis-habisan mengejar keping demi keping keduniaan. ${ }^{7}$

Fenomena di atas mengindikasikan adanya persoalan di kalangan dai dalam menyikapi tantangan dan godaan dakwah di era modern, khususnya terkait budaya materialisme, popularitas, dan gaya hidup. Para dai yang tidak sanggup menghadapi godaan tersebut, kemudian menjadi terpengaruh. Dakwah dilakukan tidak lagi dalam rangka memperbaiki dan membangun masyarakat tetapi untuk mendapatkan materi dan popularitas. Pada akhirnya, mereka akan kesulitan untuk bisa konsisten dan betul-betul menjadi teladan bagi umat. Hal yang demikian, apabila dibiarkan tentu akan menghambat kegiatan dakwah itu sendiri. Oleh karena itu, para subjek dakwah perlu menyadari dan membuat sistem antisipasi dalam menghadapi godaangodaan dakwah di era modern. Kemampuan pengelolaan atau manajemen diri yang baik menjadi salah satu kemampuan penting yang harus dimiliki seorang dai.

Hal yang juga perlu disadari oleh dai adalah bahwa agar masyarakat bisa menerima dan mengikuti kebaikan yang disyiarkan tidak cukup hanya dengan kata-kata melainkan harus diiringi dengan perbuatan. Karena perbuatan itu menjadi bukti konsistensi seorang dai antara apa yang disampaikan dengan yang dilakukannya. Dengan perbuatan itu pula masyarakat akan mendapati contoh atau keteladanan secara

http://inteleksia.stidalhadid.ac.id/index.php/inteleksi a/article/view/85.

${ }^{7}$ Adri Efferi, "Profesionalisasi Da'I Di Era Globalisasi," Jurnal Komunikasi Penyiaran Islam 1, no. 2 (2013): 91120, doi:http://dx.doi.org/10.21043/at-tabsyir.v1i2. 
langsung. Sebagaimana ditegaskan oleh Syahidin bahwa antara penyiaran, pelaksanaan, serta pengelolaan dalam kegiatan dakwah haruslah bersinambungan. ${ }^{8}$ Sehingga dai sebagai subjek, idealnya bukan hanya mampu menyampaikan materi dakwah, tetapi juga menerapkan dan mengelola dirinya dengan baik. Pengelolaan diri yang dimaksud salah satunya adalah dalam hal spiritual. Kamaluddin menyebutkan bahwa aspek spiritual merupakan salah satu kompetensi dai yang bersifat substansi. ${ }^{9}$ Mengingat lapangan dakwah berkenaan dengan nilai-nilai yang bersumber dari aspek transenden maka spiritualitas menjadi hal penting yang harus dimiliki oleh dai.

Spiritualitas dalam diri manusia tidak terlepas dari aspek kecerdasan atau yang disebut kecerdasan spiritual. Zohar dan Marshal menjelaskannya sebagai kecerdasan untuk menghadapi dan memecahkan persoalan terkait pemaknaan dan nilai, untuk kemudian bisa menempatkan perilaku dan hidup dalam konteks makna yang lebih luas dan kaya. ${ }^{10}$ Dalam konteks agama Islam, Ary Ginanjar menyebut kecerdasan spiritual sebagai kemampuan seorang muslim untuk dapat menghadirkan pemaknaan dan nilai ibadah pada setiap aktivitasnya yaitu dengan langkah-langkah dan pemikiran ketauhidan secara integralistik, dan berprinsip semata untuk Allah Swt. ${ }^{11}$ Maka, kecerdasan spiritual terkait kemampuan seseorang dalam pemaknaan dan pemberian nilai pada

\footnotetext{
8 Syahidin, Pemberdayaan Umat Berbasis Masjid (Bandung: Alfabetha, 2003), 15.

${ }^{9}$ Kamaluddin, "Kompetensi Da'i Profesional," Hikmah 02, no. 01 (2015): 104-24, http://repo.iainpadangsidimpuan.ac.id/265/1/Kamaluddin.pdf.

10 Danah Zohar dan Ian Marshal, SQ: Kecerdasan Spiritual (Bandung: Mizan, 2007), 3.
}

kehidupan, aktivitas, bahkan masalah atau kesulitan yang dia hadapi, yang dihubungkan dengan tujuan-tujuan tertinggi dan Zat yang Transenden.

Dalam perspektif manajemen SDM, aspek spiritual dewasa ini telah mendapatkan perhatian di berbagai organisasi bisnis dan perusahaan. Sebab, disadari bahwa manusia bekerja tidak hanya menggunakan tangan mereka tapi juga menggunakan hati dan jiwa mereka, manusia tidak hanya membutuhkan gaji ataupun penghargaan dalam bekerja, melainkan juga spiritualitas, suatu pekerjaan yang bermakna dan memiliki kepentingan di luar kepentingan pribadinya. ${ }^{12}$ Maka, terlebih dalam dunia dakwah, yang erat kaitannya dengan motivasi transenden. Fenomena permasalahan dai yang disebutkan di atas, bisa jadi salah satu sebabnya adalah kurangnya aspek spiritualitas. Karena dai kurang bisa memberikan pemaknaan terhadap kesulitan, godaan, dan tantangan dakwah di era modern serta menghubungkannya dengan motivasi keakhiratan akhirnya mudah terpengaruh dan menyerah pada keadaan. Oleh karenanya seorang dai harus memiliki kecerdasan spiritual yang memadai.

Kecerdasan spiritual terkait bagaimana dai dalam menghadapi lapangan dakwah di era modern memiliki kapasitas energi spiritual yang memadai. Energi spiritual berarti energi yang berhubungan dengan aspek nilai dan kebermaknaan seseorang di dalam

\footnotetext{
${ }^{11}$ Ary Ginandjar, Emotional Spiritual Quotient (Jakarta: Arga Wijaya Persada, 2001), 57.

12 Pawinee Petchsawang dan Dennis Duchon, "Measuring Workplace Spirituality in an Asian Context," Human Resource Development International 12, no. $04 \quad$ (2009): $459-68$, doi:https://doi.org/10.1080/13678860903135912.
} 
hidupnya, menghubungkannya dengan sesuatu yang besar di luar dirinya. ${ }^{13} \mathrm{Bagi}$ seorang dai nilai dan sesuatu yang besar tersebut tidak lain adalah Allah Swt.

Berdasarkan penjelasan di atas, maka seorang dai harus memiliki kemampuan mengelola energi spiritual dengan baik. Bukan sekedar mampu mengelola waktu. Sebagaimana dijelaskan Loehr dan Schawartz bahwa waktu bersifat tetap, dalam arti satu hari dua puluh empat jam, satu minggu tujuh hari, dan seterusnya. Sedangkan, energi bersifat dinamis dan dapat dikendalikan. ${ }^{14}$ Artinya energi bisa naik dan turun, dengan pengelolaan yang baik seseorang dapat memiliki kapasitas energi yang besar untuk menghadapi berbagai dinamika kehidupan. Bagi seorang dai yang menghadapi ragam tantangan dakwah, baik yang bersifat internal maupun eksternal, sangat penting untuk memiliki kemampuan mengelola energi, khususnya energi spiritual.

Guna menggali bagaimana konsep pengelolaan energi spiritual bagi dai, maka para aktivis dakwah dapat belajar dari Nabi Ibrahim. Studi ini akan mengeksplorasi bagaimana pengelolaan energi spritiual $\mathrm{Nabi}$ Ibrahim sebagai seorang dai. Pemilihan Nabi Ibrahim sebagai subjek dalam studi ini tidak lain adalah karena fenomenalnya beliau dalam hal pengelolaan energi spiritual selama dakwahnya. Hal tersebut, diindikasi dari bagaimana perjalanan dakwah $\mathrm{Nabi}$ Ibrahim, mulai dari pencarian akan kebenaran, menghadapi tantangan dakwah dari ayahnya sendiri, penolakan yang keras dari umatnya sekaligus ancaman dan siksaan dari penguasa saat itu. Dalam kehidupan

$13 \mathrm{Jim}$ Loehr dan Tony Schwartz, Terampil Mengelola Energi Bukan Waktu (Jakarta: Serambi, 2008), 226-27. pribadi, Nabi Ibrahim juga mendapatkan ujian dengan belum dikarunia anak sebagai penerusnya sampai usia senja. Dengan kapasitas energi spiritual yang baik, Nabi Ibrahim mampu menghadapi itu semua. Sampai pada ketika dikaruniai seorang putra, Nabi Ibrahim berhasil melaksanakan perintah yang sangat berat yaitu menyembelih putra kesayangannya. Kapasitas energi spiritual Nabi Ibrahim yang telah terlatih membuatnya mampu melaksanakan perintah tersebut dengan baik. Sehingga, namanya selalu dikenang, umat Nabi Muhammad diperintahkan untuk mengenang peristiwa besar penyembelihan dalam hari raya Idul Qurban, dengan harapan bisa meneladani kemampuan dan ketaatan Nabi Ibrahim yang luar biasa. Tanpa memiliki energi spiritual yang besar, maka sulit bagi Nabi Ibrahim untuk bisa menghadapi berbagai tantangan dan ujian perintah penyembelihan putranya tersebut. Dengan mempelajari bagaimana dinamika Nabi Ibrahim dalam menghadapi berbagai tantangan dan ujian dakwah dari perspektif manajemen energi spiritual akan bisa memberikan pelajaran bagi aktivis dakwah dalam mengelola energi spiritual sebagai bekal menghadapi tantangan dakwah pada era modern.

Fokus masalah dalam studi ini adalah pengelolaan energi spiritual Nabi Ibrahim dalam dinamika perjalanan dakwahnya. Tujuan studi ini adalah mendeskripsikan pengelolaan energi spiritual Nabi Ibrahim dalam menghadapi berbagai tantangan dakwah. Manfaat yang diharapkan dari studi ini adalah bisa membantu dan memperkaya referensi terkait pemecahan masalah dan pengembangan konsep pengelolaan energi

${ }^{14}$ Ibid., 17-18. 
spiritual di lapangan dakwah. Dengan pengelolaan energi spiritual yang baik di kalangan dai, diharapkan dapat menjadi bekal dalam menghadapi dinamika dakwah yang sarat dengan berbagai hambatan yang membutuhkan kapasitas energi spiritual memadai.

Metodologi dalam studi ini menggunakan pendekatan kualitatif kepustakaan. Sumber data studi ini merujuk pada kisah Nabi Ibrahim yang diceritakan dalam Al-Qur'an, dan sumber kepustakaan lain yaitu Kisah Para Nabi dan Rasul karya Ibnu Katsir, ${ }^{15}$ serta Dakwah Illahiah - Jalan Dakwah Tujuh Rasul Allah dalam Memperbaiki Masyarakat Jahiliyah karya Iskandar Al-Warisyi. ${ }^{16}$ Sumber kepustakaan tersebut dipilih karena memberikan penjelasan yang terperinci terkait perjalanan dakwah Nabi Ibrahim, reaksi masyarakat terhadap dakwah Nabi Ibrahim, dan cara Nabi Ibrahim dalam merespon reaksi masyarakatnya. Pendekatan untuk menganalisis pengelolaan energi spiritual Nabi Ibrahim merujuk pada konsep manajemen energi spiritual yang dijelaskanLoehr dan Schawartz dalam bukunya Terampil Mengola Energi Bukan Waktu. ${ }^{17}$ Sebagaimana mengelola energi pada aspek fisik maupun emosi, mengelola energi spiritual berarti berupaya meningkatkan kapasitas energi spiritual yang dimiliki, menggunakan energi tersebut

\footnotetext{
15 Ibnu Katsir, Kisah Para Nabi dan Rasul (Jakarta: AsSunnah, 2007).

${ }^{16}$ Al-Warisyi, Dakwah Illahiah - Jalan Dakwah Tujuh Rasul Allah dalam Memperbaiki Masyarakat Jahiliyah.

17 Loehr dan Schwartz, Terampil Mengelola Energi Bukan Waktu, 17-18.

18 Tri Joyo Budiono, "Pola Argumentasi Dalam Metode Dakwah Mujadalah Nabi Ibrahim," INTELEKSIA-Jurnal Pengembangan Ilmu Dakwah 02, no. 01 (2020): 1-26, http://inteleksia.stidalhadid.ac.id/index.php/inteleksi a/article/view/75/30.

${ }^{19}$ Muhammad Iqbal, "Nilai dan Strategi Dakwah dalam Kisah Nabi Ibrahim 'Alaihissalam" (STAIN
}

secara efektif efisien, serta memulihkan (recharge) energi spiritual dengan cara yang tepat. Konsep-konsep tersebut akan dieksplorasi lebih jauh dan menjadai kerangka berpikir untuk memahami pengelolaan energi spiritual Nabi Ibrahim.

Penelusuran terhadap hasil studi maupun penelitian sebelumnya, belum ditemukan yang secara spesifik membahas pengelolaan energi spiritual Nabi Ibrahim dalam dinamika dakwahnya. Di antara studi yang menjadikan Nabi Ibrahim sebagai subjek adalah, pertama, artikel jurnal "Pola Argumentasi Dalam Metode Dakwah Mujadalah Nabi Ibrahim. ${ }^{18}$ Artikel tersebut membatasi pada pola argumentasi dalam dakwah Nabi Ibrahim. Kedua, skripsi berjudul, "Nilai dan strategi dakwah dalam kisah Nabi Ibrahim 'Alaihissalam," 19 Ketiga, tesis berjudul, "Kisah Nabi Ibrahim A.S. dalam Al-Qur'an: suatu kajian semiotik." ${ }^{20}$ Dua studi terakhir yang disebutkan lebih banyak membahas strategi dakwah Nabi Ibrahim dan kisahnya dalam Al-Qur'an secara semiotik. Studi yang membahas pengelolaan energi pada lapangan dakwah adalah artikel jurnal yang berjudul, "Memaksimalkan Kinerja Organisasi Dakwah Melalui Manajemen Energi." 21 Artikel tersebut tidak secara spesifik membahas energi spiritual, tetapi energi secara umum yang perlu dikelola oleh organisasi dakwah guna meningkatkan

\footnotetext{
Padangsidimpuan, 2010), http://etd.iainpadangsidimpuan.ac.id/5565/1/05 110 133.pdf.

${ }^{20}$ Maisarah Nurhanjati, "Kisah Nabi Ibrahim di dalam Al-Quran: Suatu Kajian Semiotik," Tesis (UIN Syarif Hidayatullah, Jakarta, 2008), https://repository.uinjkt.ac.id/dspace/handle/123456 789/28214.

21 Yudi Asmara Harianto, "Memaksimalkan Kinerja Organisasi Dakwah Melalui Manajemen Energi," Jurnal Kajian dan Pengembangan Manajemen Dakwah 05 no. 02 (2015).
} 
kualitas kinerja SDM-SDM organisasi dakwah. Mengacu pada hasil penelusuran sebelumnya maka studi ini memiliki posisi yang berbeda dengan studi-studi sebelumnya, sehingga signifikan dalam pengembangan konsep pengelolaan energi spiritual, yang digali dari perjalanan dakwah Nabi Ibrahim.

\section{Dai sebagai Subjek Dakwah}

Pengertian dai merujuk pada pelaku atau subjek dan aktivis kegiatan dakwah, yaitu orang yang berusaha mewujudkan Islam dalam semua segi kehidupan, pada tataran individu, keluarga, masyarakat, dan bangsa. Dai sebagai pelaku dakwah tidak terbatas pada penceramah atau kegiatan tablig, melainkan lebih jauh dari itu, yaitu sebagai pengembang atau pembangun masyarakat. ${ }^{22}$ Oleh karena itu, dai memiliki peranan strategis dalam dakwah, sebagaimana digambarkan Thomas W. Arnold yang dikutip oleh Ali Aziz, bahwa inti dari gerakan dakwah Islam adalah terletak pada diri pendakwah. Bagaimana pun baiknya ajaran Islam, bila tidak ada subjek yang mendakwahkan, maka tidak akan mungkin bisa tersebar dan hidup di masyarakat. ${ }^{23}$

Dai sebagai salah satu unsur dalam dakwah, yaitu unsur subjek, senantiasa berhadapan dan terkait dengan unsur-unsur selainnya dalam dakwah, yaitu unsur objek atau mitra dakwah, isi pesan atau materi dakwah, metode dakwah, sarana dan media dakwah, serta efek dari pesan dakwah yang

22 Ilyas Ismail dan Prio Hotman, Filsafat Dakwah (Rekayasa Membangun Agama dan Peradaban Islam) (Jakarta: Kencana, 2011), 73-74.

${ }^{23}$ Azis, Ilmu Dakwah: Edisi Revisi, 216.

${ }^{24}$ M. Rosyid Ridla, Afif Rifa'i, dan Suisyanto, Pengantar Ilmu Dakwah: Sejarah, Perspektif, dan Ruang Lingkup, disampaikan. Unsur selainnya adalah visi atau tujuan dari dakwah itu sendiri. ${ }^{24}$ Oleh karenanya dalam dakwah, dai atau subjek perlu memiliki kompetensi tertentu, yang diperlukan guna menyampaikan pesan atau materi dakwah kepada mitra dakwah. Dalam menghadapi mitra dakwah, tidak selamanya mitra dakwah menerima pesan yang disampaikan, ada kalanya terjadi penolakan, bahkan perlawanan terhadap subjek dakwah. Untuk itu kompetensi yang perlu dimiliki tidak hanya terkait penguasaan materi dakwah, tetapi juga bekal-bekal yang dibutuhkan untuk menghadapi berbagai tantangan dakwah.

Secara umum, ditinjau dari kualitas kompetensi yang dimiliki, dai dapat dibedakan menjadi dua tingkatan, yaitu : (1) bahwa setiap muslim memiliki kewajiban sebagai pendakwah sesuai kemampuannya; (2) dai profesional, yaitu seorang muslim yang memiliki kapasitas memadai khususnya tentang pengetahuan ajaran Islam, dan ilmuilmu penunjangnya. ${ }^{25}$ Kompetensi dai yang ideal menurut Ismail dan Hotman, meliputi: (1) kekuatan intelektual meliputi wawasan Keislaman, sejarah, bahasa dan sastra, ilmuilmu sosial, iptek, dan dunia kontemporer; (2) keterampilan; (3) sikap dan moral, di antaranya kasih sayang, integritas dan keteladanan, kerja keras, dan sabar; (4) kekuatan spiritual, meliputi bekal iman, ibadah, dan takwa. ${ }^{26}$ Kamaluddin juga menjelaskan bahwa kompetensi pendakwah meliputi: (1) kompetensi spiritual (ruhaniyyah) yaitu memiliki sifat-sifat iman dan takwa, ahli taubat dan ibadah; (2)

Metode Dakwah (Yogyakarta: Samudra Biru, 2017), 33, http://digilib.uin-suka.ac.id/id/eprint/29320.

${ }^{25}$ Kamaluddin, “Kompetensi Da'i Profesional," 118-19.

${ }^{26}$ Ismail dan Hotman, Filsafat Dakwah (Rekayasa Membangun Agama dan Peradaban Islam). 77-120. 
kompetensi intelektual ('aqliyah) atau kompetensi profesional; (3) kompetensi moral (khulqiyah), di antaranya dengan meneladani nabi yang bersifat sidiq, amanah, tablig dan fatanah, bersyukur, ikhlas, ramah dan penuh pengertian, tawadlu', sederhana dan jujur, tidak egois, tegas, tanggung jawab, sabar dan tawakal, terbuka (demokratis) dan lemah lembut; (4) kompetensi fisik material (Jasmaniyah), yang berarti hendaklah dai adalah orang yang sehat jasmani, memiliki kecukupan materi serta berasal dari etnik kaum sendiri. ${ }^{27}$

Berdasarkan penjelasan beberapa ahli di atas, dapat disimpulkan bahwa kompetensi spiritual menjadi salah satu dimensi penting yang harus dimiliki oleh seorang dai. Terlebih bagi mereka yang menjadi dai profesional. Dengan memiliki kompetensi spiritual akan memudahkan bagi dai untuk menghadapi tantangan-tantangan dakwah. Ketika menghadapi tantangan dakwah, pasti membutuhkan energi besar, yang tidak jarang memerlukan pengorbanan, baik secara material maupun imaterial, dengan memiliki kompetensi spiritual yang memadai, maka seorang dai akan sanggup menghadapi kesulitan-kesulitan tersebut.

\section{Keterampilan Mengelola Energi Spiritual}

Pengelolaan energi spiritual tidak bisa dilepaskan dari konsep energi dan pentingnya energi untuk dikelola. Energi yang menjadi faktor utama tingginya kinerja seseorang dan bertahan. Semua hal yang dilakukan dalam pekerjaan, interaksi dengan

\footnotetext{
${ }^{27}$ Kamaluddin, “Kompetensi Da'i Profesional," 118-19.

28 Loehr dan Schwartz, Terampil Mengelola Energi Bukan Waktu. 17-18.
}

kolega, pengambilan keputusan penting hingga meluangkan waktu dengan keluarga selalu memerlukan energi. Tanpa energi dengan kuantitas, kualitas, fokus, dan kekuatan yang memadai seseorang tidak akan dapat bekerja dengan performa terbaik. Dengan terampil mengelola energi memungkinkan seseorang untuk terlibat penuh dalam setiap aktivitasnya. ${ }^{28}$

Agar bisa terlibat penuh maka fisik harus kuat, emosi harus terhubung, mental terarah, dan secara spiritual terjalin dengan nilai atau tujuan di luar kepentingan pribadi semata. Fisik, emosi, mental, dan spiritual adalah empat sumber energi manusia yang sangat penting, dan perlu dikelola dengan baik. ${ }^{29}$ Adapun penjelasannya sebagai berikut: Pertama, energi fisik. Energi fisik adalah sumber utama bahan bakar seseorang untuk bekerja dan beraktivitas. Energi fisik juga akan mempengaruhi kemampuan seseorang dalam menata emosi, konsentrasi, kreatifitas, bahkan komitmen terhadap misi atau nilai-nilai. Energi fisik pada dasarnya didapat dari interaksi antara oksigen (pernafasan) dan glukosa (makanan). ${ }^{30}$ Melalui proses metabolisme tubuh menghasilkan energi fisik yang memungkinkan untuk digunakan menggerakkan otot-otot dan syaraf-syaraf tubuh. Apabila energi fisik tercukupi maka seseorang akan berada dalam kondisi yang sehat dan bugar. Artinya, dia memiliki kapasitas yang memadai untuk melakukan berbagai aktivitas fisik, tidak mudah Lelah, dan tetap prima. Sebaliknya, apabila energi fisik kekurangan maka seseorang akan merasa mudah lelah, fisik lemah, tidak mampu melakukan aktivitas fisik berat,

\footnotetext{
${ }^{29}$ Ibid., 18.

30 Ibid., 130.
} 
bahkan ada penyakit dalam tubuhnya. Makan bergizi, minum yang cukup, istirahat, dan latihan fisik secara berselang adalah variable-variabel penting untuk membangun kekuatan dan meningkatkan kapasitas otototot energi fisik.

Kedua, energi emosi. Energi emosi merupakan hasil dari proses emosi seseorang. Agar dapat menampilkan kinerja terbaik maka seseorang harus bisa merasakan emosi positif dan menyenangkan (cinta, bahagia, rasa syukur). Bentuknya berupa kenikmatan, tantangan, petualangan, dan kesempatan. Sementara emosi yang bersifat negatif yaitu yang berasal dari ancaman, ketakutan, frustasi, kemarahan, cenderung meracuni dan terkait erat dengan pengeluaran hormon stress tertentu. Emosi-emosi negatif dapat menyelamatkan seseorang, tetapi akan sangat menguras energi dan membuatnya tidak efisien dalam konteks kinerja. ${ }^{31}$ Apabila energi emosi positif tercukupi maka seseorang akan mendapatkan kepercayaan diri, pengendalian diri, kecakapan sosial, empati, dan kesenangan. Sebaliknya, apabila energi emosi kekurangan maka seseorang akan menjadi kurang percaya diri, kurang sabar, dan tidak bisa mengendalikan diri. Kesabaran, empati, dan kepercayaan diri menjadi otot-otot emosional yang dapat diperkuat dalam cara yang sama memperkuat otot fisik, yaitu dengan memacunya sampai melewati batas-batas seraya diikuti pemulihan. ${ }^{32}$

Ketiga, energi mental. Energi mental terkait kapasitas mental yang digunakan untuk menata hidup dan memfokuskan perhatian dan konsentrasi, sehingga seseorang bisa

31 Ibid., 166

32 Ibid., 167. terlibat penuh dalam kinerjanya. Energi mental yang didapat dari cara berpikir yang positif yang menghasilkan optimisme dan mendukung keteguhan dan ketekunan. Otot pendukung utama yang menggerakkan energi mental secara optimal antara lain adalah persiapan mental, visualisasi, bincang-bincang yang positif dengan diri sendiri, manajemen waktu yang efektif, dan kreativitas. Kapasitas mental yang maksimum didapat dari keseimbangan antara pengeluaran dan pemulihan energi mental. ${ }^{33}$ Sehingga apabila energi mental ini terpenuhi, maka seseorang akan merasakan optimisme, selalu mencoba bekerja secara positif, memiliki kekuatan dan ketahanan dalam tekanan maupun hinaan. Kekurangan energi mental akan membuat seseorang tidka mampu untuk konsentrasi dan fokus, serta pesimis terhadap apa yang dikerjakannya.

Keempat, energi spiritual. Energi spiritual terkait motivasi seseorang untuk mengeluarkan apa yang dimilikinya, yang merupakan daya unik untuk menggerakkan kegiatan dalam setiap dimensi kehidupan. Energi spiritual juga terkait keterhubungan seseorang dengan seperangkat nilai yang dipegang teguh dan dengan tujuan di luar kepentingan pribadi. Otot utama yang menggerakkan energi spiritual adalah karakter keberanian dan pendirian untuk hidup berdasarkan nilai-nilai yang diyakini, sekalipun diperlukan pengorbanan pribadin dan mengalami berbagai kesulitan dalam menjalaninya. Otot-otot pendukungnya antara lain adalah semangat, komitmen, integritas, dan kejujuran. ${ }^{34}$

\footnotetext{
33 Ibid., 169-72.

34 Ibid., 226-27.
} 
Keterlibatan penuh (full enganggement) pada pekerjaan dan aktivitas adalah bentuk pengeluaran energi yang mampu menghasilkan kinerja terbaik. Hal tersebut mengjadi indikasi pengelolaan energi yang memadai pada diri seseorang. Ada empat hal yang menjadi prinsip dalam pengelolaan energi agar dapat menghasilkan keterlibatan penuh. Prinsip pertama, menyelaraskan empat sumber energi yang berbeda namun terjalin satu sama lain, yaitu energi fisik, emosional, mental, dan spiritual. Kekurangan salah satu dimensi energi akan berpotensi memerosotkan kinerja. Untuk bisa melibatkan diri secara penuh diperlukan kekuatan, ketahanan, keluwesan, dan keuletan dalam semua dimensi energi. Prinsip kedua, menyeimbangkan pengeluaran energi dengan memperbaruinya secara berselang. Harus disadari bahwa kapasitas energi pada semua dimensi bisa berkurang karena terlalu banyak digunakan atau terlalu sedikit digunakan (energi melemah). Untuk mempertahankan denyut kuat dalam hidup, seseorang harus belajar memperbarui energi dalam ritme yang tepat. Sehingga kehidupan yang paling produktif dan bahagia ditandai dengan kemampuan untuk terlibat penuh dalam kinerja dan tantangan yang dihadapi, melepaskan diri pada waktu-waktu tertentu, dan melakukan pembaruan energi. ${ }^{35}$

Prinsip ketiga, membangun/meningkatkan kapasitas energi dengan memacu dirihingga keluar ambang batas normal, berlatih secara sistematis sebagaimana yang dilakukan elite atlet. Stres bukanlah musuh kehidupan. Stres malah menjadi kunci bagi pertumbuhan. Sebagaimana membangun kekuatan otot dengan terus membuatnya

35 Ibid., 25-30. stress secara sistematis, lalu diberikan pemulihan yang memadai, maka otot akan tumbuh lebih kuat dan lebih baik menghadapi stimulus berikutnya. Maka, dalam membangun kapasitas energi lainnya (emosional, mental, dan spiritual) dapat dilakukan dengan cara yang persis sama, yaitu dengan memberikan stress/tekanan terukur yang menimbulkan dan diikuti dengan proses pemulihan yang memadai. Prinsip keempat, membangun ritual energi yang positif, yaitu rutinitas-rutinitas yang sangat spesifik untuk mengatur energi. Ritual dalam hal ini tidak selalu terkait agama tetapi dalam arti lebih luas. Ritual positif merupakan perilaku yang makin lama menjadi otomatis, tersulut oleh nilai yang dipegang teguh. Dengan memiliki ritual positif memungkinkan seseorang untuk memngatur energi secara efektif dalam rangka keterlibatan penuh. ${ }^{36}$

Berdasarkan penjelasan prinsip pengelolaan energi di atas, maka keterampilan mengelola energi meliputi, pertama, mampu meningkatkan kapasitas energi, artinya energi yang dimiliki terus ditingkatkan secara kekuatan, keluwesan, ketahanan, dan keuletan. Peningkatan kapasitas pada semua dimensi energi dilakukan dengan berbagai latihan yang sampai menyentuh ambang batas normal dan pemulihan yang baik. Dengan pola latihan dan pemulihan yang seimbang pada semua dimensi energi akan mampu meningkatkan kapasitas energi tersebut. Kedua, menerapkan cara menyulut atau membangkitkan energi secara efektif dan efisien. Artinya, dapat dengan tepat menggunakan energi yaitu saat energi tinggi, dan lebih banyak menggunakan energi yang bersifat positif. Ketiga, memiliki cara

\footnotetext{
36 Ibid., 30-34.
} 
pemulihan energi yang tepat. Pemulihan energi terkait kemampuan untuk melepaskan diri dari aktivitas atau pekerjaan pada waktu tertentu secara terukur, serta mampu membangun ritual-ritual energi yang positif.

Studi ini, memfokuskan pada keterampilan mengelola energi spiritual. Energi spiritual sebagaimana disebut di atas terkait sumber motivasi, semangat, arahan, dan ketekunan, energi yang membuat seseorang totalitas mengeluarkan apa saja yang dimiliki. Apabila energi spiritual tersebut tercukupi maka akan memunculkan karakter keberanian, semangat, pantang menyerah, dengan komitmen tinggi, serta keterlibatan penuh untuk selalu terhubung dan berpegang teguh mewujudkan sesuai dengan nilainilainya. Sebaliknya, apabila seseorang mengalami kekurangan energi spiritual maka yang terjadi adalah tidak ada semangat, tidak ada komitmen dan pendirian, ketidakpuasan, takut akan konflik, dan akhirnya adalah keterlepasan dia dengan seperangkat nilai yang diyakininya. Seseorang yang level energi spiritualnya pada tingkat renah akan kesulitan dalam menghadapi bencana atau tragedi. Dia tidak akan mampu bertahan dan tidak siap menderita untuk situasi yang sulit. Ketika energi spiritual habis atau pada titik terendah, maka dia tidak memiliki kekuatan, keberanian berkorban, dan motivasi untuk memberikan yang terbaik demi nilai-nilai yang dipegang teguhnya. Keberadaan energi spiritual yang memadai juga dapat menggerakkan optimisme dan harapan untuk terus melangkah, karena dia senantiasa terhubung dengan nilai-nilai, sesuatu di luar dirinya. Oleh karena itu, ditinjau dari kapasitas energi spiritualnya, meraka yang menghasilkan karya besar, memiliki performa tinggi, dan konsisten pada komitmen dan nilai-nilainya adalah mereka yang memiliki energi spiritual yang memadai. Tentu untuk bisa memiliki kapasitas energi spiritual yang demikian haruslah didukung dengan sumber energi selainnya.

Sama halnya dengan sumber energi selainnya, dalam keterampilan pengelolaan energi spiritual mencakup, pertama, kemampuan meningkatkan kapasitas energi spiritual. Peningkatan kapasitas energi berarti melatih otot-otot terkait spiritualitas sampai pada ambang batas dan melakukan pemulihan secara seimbang. Mengembangkan kapasitas spiritual membutuhkan pengabaian atas kebutuhan pribadi demi tujuan yang luhur. Dibutuhkan keberanian untuk melakukan hal tersebut karena mengabaikan kepentingan pribadi akan menimbulkan kekhawatiran dan ketakutan akan kebutuhan kehidupan. Namun, sebenarnya menempatkan kepentingan pribadi dibawah sesuatu yang lebih tinggi akan dapat merasakan sensai yang lebih dalam aras makna dan martabat diri yang lebih tinggi. Komitmen untuk hidup sesuai dengan nilai-nilai terdalam (spiritual) akan mampu menciptakan stabilitas dalam hidup dan membantu mengelola kesulitan serta tantangan dalam hidup. Oleh karena itu, dalam upaya meningkatkan kapasitas energi spiritual, seseorang harus mampu memberikan makna pada kehidupannya. ${ }^{37}$ Dengan demikian, maka otot-otot terkait energi spiritual yaitu karakter keberanian, pendirian dan komitmen untuk menegakkan nilai-nilai, kesediaan berkorban dan

37 Ibid., 209-10. 
menderita untuk kepentingan yang lebih besar akan terlatih yang pada akhirnya akan meningkatkan kapasitas energi spiritual.

Kedua, mampu menjaga cadangan energi spiritual dengan baik, yaitu dengan menyeimbangkan antara komitmen terhadap nilai-nilai yang diyakini dengan kepedulian terhadap diri yang memadai. Artinya, kapasitas seseorang untuk hidup dengan nilai-nilai yang dipegang teguh bergantung pula dengan pemulihan semangat secara teratur, untuk beristirahat, memulihkan, dan menghubungkan kembali dengan nilai-nilai tersebut. ${ }^{38}$ Ritual-ritual energi spiritual yang positif menjadi cara bagi seseorang untuk menjaga agar cadangan energi spiritualnya senantiasa mencukupi. Loehr dan Schwartz mencontohkan ritual energi spiritual seperti menanyakan pada diri terkait komitmen, meluangkan waktu untuk bertanya terkait keyakinan, makna hidup bahkan dalam situasi menderita sekalipun. ${ }^{39}$ Jika dikaitkan dengan agama, maka sebenarnya dalam agama juga mengatur kegiatan-kegiatan ritual yang jika dilaksanakan dengan baik akan dapat menjadi sarana pemulihan dan menjaga cadangan energi spiritual.

Ketiga, mampu menggunakan energi spiritual secara efisien. Dengan kata lain terdapat teknik efisiensi dalam penggunaan maupun pemulihan energi spiritual. Efisiensi dalam penggunaan terkait bagaimana lebih banyak menggunakan energi yang positif dengan kapasitas dan cadangan energi yang memadai. Efisiensi dalam pemulihan terkait penggunaan teknik-teknik ritual yang tepat dan sejalan dengan nilai-nilai yang dianut.
Loehr dan Schawrtz memang tidak membatasi definisi spiritual dalam pengertian agama. Namun, bukan berarti nilai agama atau motivasi ketuhanan tidak dapat menjadi energi spiritual. Karena nilainilai Ketuhanan adalah aspek transenden yang dapat menjadi kepentingan dan tujuan hidup seseorang, sehingga dia bersedia menempatkan kepentingan pribadinya dibawah kepentingan agama atau nilai-nilai Ketuhanannya. Studi ini, menjadikan Nabi Ibrahim sebagai subjek pengelola energi spiritual dalam menghadapi dinamika dakwahnya. Aspek spiritualitas yang dijadikan titik tolak adalah nilai-nilai Ketuhanan yang diyakininya secara rasional, dimana Nabi Ibrahim kemudian mendapatkan tugas untuk mendakwahkan nilai-nilai tersebut.

Keterampilan mengelola energi spiritual yang sudah diuraikan di atas menjadi kerangka berpikir guna menggali bagaimana Nabi Ibrahim sebagai dai mengelola energi spiritualnya, sehingga berhasil melaksanakan tugasnya, menghadapi berbagai tantangan dan kesulitan dakwah, bahkan menunaikan perintah yang luar biasa berat yaitu menyembelih putra tercintanya. Selanjutnya, akan diuraikan bagaimana dinamika perjalanan dakwah Nabi Ibrahim, yang menjadi bahan analisis dalam pengelolaan energi spiritualnya. Berikut gambaran sketsa kerangka berpikir dalam studi ini. 


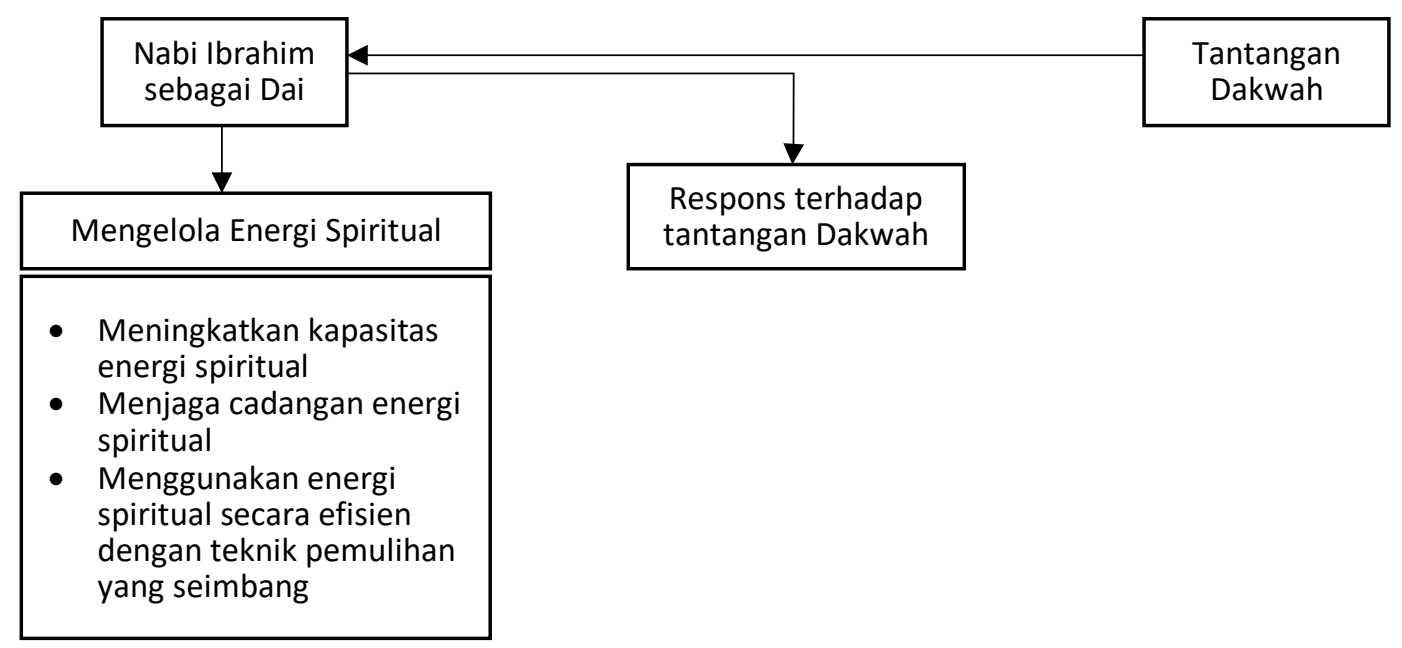

Gambar 1 - Sketsa Kerangka Berpikir Pengelolaan Energi Spiritual Nabi Ibrahim

\section{Dinamika Dakwah Nabi Ibrahim}

Sebagai seorang Nabi, Ibrahim tidak hanya dikenal dalam agama Islam, tetapi juga Yahudi dan Kristen. Ketiga agama samawi tersebut bahkan menempatkan beliau sebagai bapak para nabi. Hal tersebut, karena dari keturunan Nabi Ibrahim lah sebagian besar nabi-nabi yang dikenal. Ibrahim atau yang disebut Abraham/Abram dalam tradisi bangsa Yahudi dianggap sebagai leluhur mereka. Nabi Muhammad sendiri sebagai nabi akhir zaman yang diutus untuk seluruh umat manusia juga merupakan keturunan Nabi Ibrahim melalui putranya Nabi Ismail. Ibrahim sendiri menurut penuturan Ibnu Katsir adalah keturunan Nabi Nuh. la adalah Ibrahim bin Tarikh bin Nahur bin Sarugh bin Ra'u bin Faligh bin Abir bin Syalih bin Arfakhsyadz bin Sam bin Nuh. ${ }^{40}$ la dilahirkan di sebuah tempat yang Bernama Faddam Aram wilayah kerajaan Babilonia. Babilonia sendiri saat itu

40 Katsir, Kisah Para Nabi dan Rasul, 183.

41 Al-Warisyi, Dakwah Illahiah - Jalan Dakwah Tujuh Rasul Allah dalam Memperbaiki Masyarakat Jahiliyah, 225. merupakan kerajaan yang makmur, rakyatnya hidup senang dan sejahtera. Segala kebutuhan sandang, pangan, dan papan maupun kebutuhan jasmani lainnya terpenuhi dengan baik. Namun, secara tingkat rohani masih berada pada tingkat jahiliyah. Mereka tidak mengenal Allah, Tuhan Pencipta Semesta Alam. Mereka menyembah patung-patung yang mereka buat sendiri dari batu atau dari lumpur dan tanah. ${ }^{41}$ Ada juga yang menjelaskan bahwa sebagian masyarakat tempat Ibrahim berdakwah adalah masyarakat yang menyembah bintang dan benda-benda langit lainnya. ${ }^{42}$

Penguasa Babilonia saat itu adalah seorang raja Bernama Namrud yang menjalankan pemerintahannya dengan tangan besi dan kekuasaan mutlak. Raja Namrud adalah seorang yang melampaui batas, zhalim, sewenang-wenang, serta mengutamakan

\footnotetext{
42 Katsir, Kisah Para Nabi dan Rasul, 184.
} 
kehidupan dunia. Kekuasaan mutlak yang ada di tangannya dan segala kemewahan hidup lama kelamaan menjadikannya tidak puas. Sampai kemudian dia merasa dirinya layak untuk disembah oleh rakyatnya sebagai Tuhan. Dengan kekuasaan yang dia miliki, dia merasa bisa mengubah yang miskin menjadi kaya, yang hidup menjadi mati, yang hina menjadi mulia. Disamping itu, dia adalah seorang raja, penguasa yang memiliki negara besar. ${ }^{43}$ Dalam keadaan masyarakat yang demikianlah, Allah kemudian mengutus Ibrahim sebagai NabiNya untuk menyampaikan risalah tauhid kepada masyarakatnya.

Dinamika perjalanan dakwah yang dihadapi Nabi Ibrahim akan digambarkan dalam enam babakan besar, yaitu: (1) Allah mengangkat Ibrahim menjadi Nabi dan memberinya petunjuk; (2) Dakwah Nabi Ibrahim kepada bapaknya; (3) Dakwah Nabi Ibrahim kepada masyarakatnya dengan pendekatan empiris; (4) Dakwah Nabi Ibrahim kepada Raja Namrud; (5) Hijrahnya Nabi Ibrahim; (6) Ujian perintah menyembelih putranya.

Pertama, Allah mengangkat Ibrahim menjadi Nabi dan memberinya petunjuk-petunjuk. Dalam proses perbaikan masyarakat jahiliyah menjadi mayarakat thoyibah, Allah senantiasa mengangkat seseorang dari masyarakat tersebut sebagai utusanNya. Dalam hal ini, untuk memperbaiki masyarakat Babilonia, Allah mengangkat Nabi Ibrahim. Untuk itu Allah memberikan petunjuk-petunjukNya kepada Nabi Ibrahim, sebagaimana dikisahkan dalam QS. AlAn'am:76-79, Ketika malam telah menjadi gelap, dia (Ibrahim) melihat sebuah bintang

\footnotetext{
${ }^{43}$ Al-Warisyi, Dakwah Illahiah - Jalan Dakwah Tujuh Rasul Allah dalam Memperbaiki Masyarakat Jahiliyah, 227.
}

(Ialu) dia berkata, "Inilah Tuhanku." Maka ketika bintang itu terbenam dia berkata, "Aku tidak suka kepada yang terbenam." Lalu ketika dia melihat bulan terbit dia berkata, "Inilah Tuhanku." Tetapi ketika bulan itu terbenam dia berkata, "Sungguh, jika Tuhanku tidak memberi petunjuk kepadaku, pastilah aku termasuk orangorang yang sesat." Kemudian ketika dia melihat matahari terbit, dia berkata, "Inilah Tuhanku, ini lebih besar." Tetapi ketika matahari terbenam, dia berkata, "Wahai kaumku! Sungguh, aku berlepas diri dari apa yang kamu persekutukan." Aku hadapkan wajahku kepada (Allah) yang menciptakan langit dan bumi dengan penuh kepasrahan (mengikuti) agama yang benar, dan aku bukanlah termasuk orang-orang musyrik. ${ }^{44}$

Ayat di atas menggambarkan bagaimana dinamika Nabi Ibrahim dalam mendapatkan petunjukNya tentang kebenaran Allah sebagai Pencipta. Allah memperlihatkan kepada Ibrahim tanda-tanda kebesaranNya yang ada di langit, maupun yang ada di bumi. Dengan pengamatan yang mendalam terhadap tanda-tanda tersebut yaitu terhadap bulan, bintang, matahari, dan sebagainya sampai Nabi Ibrahim pada kesimpulan bahwa Tuhannya adalah yang di menciptakan itu semua. Bulan, bintang, dan matahari adalah makhluk yang tunduk kepada Tuhan, sehingga tidak layak untuk dijadikan sesembahan. Sehingga, secara rasional dan didukung cita rasa yang tinggi Nabi Ibrahim dapat menangkap petunjuk akan keberadaan dan kebesaran Sang Pencipta. Sampai la terperangah dan berkata: "Sesungguhnya aku berlepas diri dari apa yang kamu persekutukan."

\footnotetext{
${ }^{44}$ LPMQ Kemenag, “Qur’an Kemenag,” 2021, a. QS. AlAn'am:76-79, 07 Agustus 2021, https://quran.kemenag.go.id/.
} 
Pernyataan tersebut menunjukkan bahwa sebagian masyarakatnya mempercayai benda-benda langit itu sebagai sesembahannya. Namun, petunjuk dari Tuhannya telah menyadarkan Nabi Ibrahim bahwa masyarakatnya keliru, dan dia berlepas diri dari apa yang disembah oleh kaumnya. Dengan keimanan yang semacam itulah, yaitu keimanan yang didasari pengetahuan, Nabi Ibrahim mendakwahkan nilai-nilai tauhid di masyarakatnya.

Kedua, Dakwah Nabi Ibrahim kepada bapaknya. Dakwah yang pertama kali diserukan Nabi Ibrahim adalah kepada bapaknya, yaitu Tarekh (Terah) atau Azar. Bapaknya termasuk penyembah berhala, dan berprofesi sebagai pembuat patung berhala. Dengan keyakinan Tauhid yang kuat, dan bahsa yang halus, Nabi Ibrahim mencoba menyampaikan kesesatan menyembah berhala. Allah menceritakan kisah tersebut dalam QS. Maryam ayat 4248, (Ingatlah) ketika dia (Ibrahim) berkata kepada ayahnya, "Wahai ayahku! Mengapa engkau menyembah sesuatu yang tidak mendengar, tidak melihat, dan tidak dapat menolongmu sedikit pun? Wahai ayahku! Sungguh, telah sampai kepadaku sebagian ilmu yang tidak diberikan kepadamu, maka ikutilah aku, niscaya aku akan menunjukkan kepadamu jalan yang lurus. Wahai ayahku! Janganlah engkau menyembah setan. Sungguh, setan itu durhaka kepada Tuhan Yang Maha Pengasih. Wahai ayahku! Aku sungguh khawatir engkau akan ditimpa azab dari Tuhan Yang Maha Pengasih, sehingga engkau menjadi teman bagi setan." Dia (ayahnya) berkata, "Bencikah engkau kepada tuhan-tuhanku, wahai Ibrahim? Jika engkau tidak berhenti, pasti engkau akan

${ }^{45}$ Ibid., a. QS. Maryam:42-48. kurajam, maka tinggalkanlah aku untuk waktu yang lama." Dia (Ibrahim) berkata, "Semoga keselamatan dilimpahkan kepadamu, aku akan memohonkan ampunan bagimu kepada Tuhanku. Sesungguhnya Dia sangat baik kepadaku. Dan aku akan menjauhkan diri darimu dan dari apa yang engkau sembah selain Allah, dan aku akan berdoa kepada Tuhanku, mudah-mudahan aku tidak akan kecewa dengan berdoa kepada Tuhanku." 45

Dari ayat di atas diketahui bahwa telah terjadi dialog dan perdebatan antara Ibrahim dan bapaknya. Nabi Ibrahim telah berupaya menyerukan kebenaran kepada bapaknya dengan cara yang lemah lembut dan baik. Namun respon yang didapatkan ternyata Bapkanya menolak seruan kebenaran dari Nabi Ibrahim. Dia memilih untuk tetap mempercayai kepercayaan leluhurnya menyembah berhala. Tidak hanya itu, Tarekh sangat marah dengan kelakukan anaknya, menganggap anaknya kurang ajar sudah menghina Tuhannya. Bahkan mengancam Nabi Ibrahim akan dirajam apabila tidak berhenti mendakwahinya, dan mengusirnya untuk waktu yang lama. Dalam keadaan demikian, respon Nabi Ibrahim menghadapi ancaman dan pengusiran bapaknya adalah Beliau menerima dan tidak sakit hati kepada bapanya. Malah Nabi Ibrahim kemudian mendoakan keselamatan dan kebaikan untuk bapaknya agar suatu saat bisa menyadari kesalahannya. Ibrahim pun kemudian pergi dan berlepas diri dari bapaknya dan apa yang disembah bapaknya. ${ }^{46}$

Ketiga, Dakwah Nabi Ibrahim kepada masyarakatnya dengan pendekatan empiris.

\footnotetext{
${ }^{46}$ Katsir, Kisah Para Nabi dan Rasul, 186-87.
} 
Dikisahkan bahwa setiap tahun masyarakat Babilonia ke luar kota beramai-ramai pada suatu hari raya yang dianggap keramat. Berhari-hari mereka di luar kota dalam keadaan suka ria, sehingga keadaan kota hampir kosong. Situasi tersebut dipandang kesempatan bagi Nabi Ibrahim untuk menghancurkan patung-patung berhala yang kecil dan menyisakan patung yang paling besar. Hal itu, dilakukan sebagai sistem untuk membangkitkan kesadaran masyarakatnya tentang kekeliruan konsep ketuhanannya. Ketika penduduk kota kembali dari perayaan, mereka sangat terkejut mendapati tuhan-tuhan mereka terpotong-potong. Mereka bertanya-tanya siapa yang melakukan tindakan tersebut. Sebagian penduduk menuduh Ibrahim yang melakukannya. Oleh karena itu, ia kemudian dipanggil untuk disidang. Dengan disaksikan masyarakat terbuka terjadilah dialog dan Ibrahim menyatakan bahwa yang menghancurkan patung-patung kecil itu tidak lain adalah patung yang paling besar. ${ }^{47}$ Pernyataan itu jelas sebagai suatu serangan terhadap kepercayaan kaumnya agar mereka menyadari bahwa patung yang disembah itu tidak bisa berbuat apa-apa.

Dialog tersebut direkam dalam QS. Al-Anbiya 52-67, Maka dia (Ibrahim) menghancurkan (berhala-berhala itu) berkeping-keping, kecuali yang terbesar (induknya); agar mereka kembali (untuk bertanya) kepadanya. Mereka berkata, "Siapakah yang melakukan (perbuatan) ini terhadap tuhantuhan kami? Sungguh, dia termasuk orang yang zalim." Mereka (yang lain) berkata, "Kami mendengar ada seorang pemuda yang mencela (berhala-berhala ini),

47 Al-Warisyi, Dakwah Illahiah - Jalan Dakwah Tujuh Rasul Allah dalam Memperbaiki Masyarakat Jahiliyah, 228. namanya Ibrahim." Mereka berkata, "(Kalau demikian) bawalah dia dengan diperlihatkan kepada orang banyak, agar mereka menyaksikan." Mereka bertanya, "Apakah engkau yang melakukan (perbuatan) ini terhadap Tuhan-Tuhan kami, wahai Ibrahim?" Dia (Ibrahim) menjawab, "Sebenarnya (patung) besar itu yang melakukannya, maka tanyakanlah kepada mereka, jika mereka dapat berbicara. " Maka mereka kembali kepada kesadaran mereka dan berkata, "Sesungguhnya kamulah yang menzalimi (diri sendiri)." Kemudian mereka menundukkan kepala (lalu berkata), "Engkau (Ibrahim) pasti tahu bahwa (berhala-berhala) itu tidak dapat berbicara." Dia (Ibrahim) berkata, "Mengapa kamu menyembah selain Allah, sesuatu yang tidak dapat memberi manfaat sedikit pun, dan tidak (pula) mendatangkan mudarat kepada kamu? Celakalah kamu dan apa yang kamu sembah selain Allah! Tidakkah kamu mengerti?"48

Apa yang disampaikan oleh Ibrahim kepada masyarakatnya adalah bukti telak bahwa patung-patung itu lemah dan tidak layak untuk disembah. Meski demikian nyata bukti yang disampaikan oleh Nabi Ibrahim, respon masyakatnya justru tetap kukuh tidak mau menerima kebenaran. Mereka tidak sedikit pun mempercayai peringatan yang dibawa oleh Nabi Ibrahim. Mereka lebih memilih tetap berpegang teguh pada tradisi leluhurnya dalam penyembahan berhala. Karena merasa terhina dan kalah telak dari argumen yang disampaikan Nabi Ibrahim, masyarakatnya menjadi marah dan menginginkan agar Nabi Ibrahim dihukum. Dalam QS. Al-Anbiya: 68, disebutkan,

${ }^{48}$ Kemenag, "Qur'an Kemenag," a. QS. Al-Anbiya:5267. 
Mereka berkata, "Bakarlah dia dan bantulah tuhan-tuhan kamu, jika kamu benar-benar hendak berbuat." Kami (Allah) berfirman, "Wahai api! Jadilah kamu dingin, dan penyelamat bagi Ibrahim!" Dan mereka hendak berbuat jahat terhadap Ibrahim, maka Kami menjadikan mereka itu orangorang yang paling rugi. ${ }^{49}$

Menyikapi respon dari masyarakatnya yang hendak membakarnya, Nabi Ibrahim hanya bisa berdoa dan berucap, "Tiada Tuhan yang berhak disembah selain Allah. Maha Suci Engkau. Segala puji dan kekyasaan hanya kepunyaanMu. Tiada sekutu bagiMu." Dan ketika Nabi Ibrahim dilempar ke kobaran api yang besar, ia berucap, "Cukuplah Allah sebagai pelindung kami, dan Allah adalah sebaik-baik pelindung." Dalam situasi yang genting itulah, Allah menyelamatkan Nabi Ibrahim dengan memerintahkan api menjadi dingin dan menjadi keselamatan bagi Nabi Ibrahim. ${ }^{50}$

Keempat, dakwah Nabi Ibrahim kepada Raja Namrud. Ulah Nabi Ibrahim mulai dari ajaran dakwahnya, penghancuran berhala, dan tidak terbakarnya Ibrahim sewaktu dihukum terdengar oleh Raja Namrud. Ia mulai khawatir bila Ibrahim akan melemahkan kekuasaannya. Maka, dipanggilah Ibrahim menghadap kepadanya dan terjadilah perdebatan tentang konsep Tauhid. Raja Namrud sangat percaaya diri dengan kekuasaannya, yang menjalankan pemerintahanya secara mutlak. Ketika nabi Ibrahim menjelaskan bahwa Tuhannya adalah yang menciptakan, menghidupkan, dan mematikan makhluknya, Raja Namrud

${ }^{49}$ Ibid., a. QS. Al-Anbiya:68-70.

${ }^{50}$ Katsir, Kisah Para Nabi dan Rasul, 197-98.

${ }^{51}$ Al-Warisyi, Dakwah Illahiah - Jalan Dakwah Tujuh Rasul Allah dalam Memperbaiki Masyarakat Jahiliyah, 229. kemudian membantahnya. "Jika Tuhanmu yang engkau sembah dapat menghidupkan dan mematikan, Aku pun dapat berbuat demikian. Seseorang yang menjalani hukuman mati, bila Aku beri ampun maka berarti Aku telah membuatnya hidup. Dan bila Aku jatuhi hukuman mati, maka berarti Dia akan mati. Dengan demikian tidak ada bedanya Tuhanmu dan Aku, mengapa engkau tidak menyembahku saja?" 51 Menghadapi argumentasi tersebut, Nabi Ibrahim menjawab sebagaimana disebutkan dalam QS. Al-Baqarah: 258, Ibrahim berkata, "Allah menerbitkan matahari dari timur, maka terbitkanlah ia dari barat." Maka bingunglah orang yang kafir itu (Raja Namrud). Allah tidak memberi petunjuk kepada orang-orang zalim. ${ }^{52}$

Dalam perdebatan tersebut nampak bahwa Raja Namrud tidak bisa lagi berargumentasi. Dia tidak bisa membantah kebenaran ajaran tauhid yang disampaikan oleh Nabi Ibrahim. Sekalipun demikian, Raja tetap menolak seruan kebenaran dari Nabi Ibrahim. Bahkan diriwayatkan, Sang Raja tidak memberi subsidi makanan kepada keluarga Nabi Ibrahim, sementara masyarakat yang lain mendapatkannya. $53 \mathrm{Hal}$ tersebut, menunjukkan bahwa Raja Namrud masih terus menekan dakwah Nabi Ibrahim. Raja memang bersikap seakan-akan acuh tak acuh terhadap gerak-gerik dakwah Nabi Ibrahim dan membiarkannya tetap tinggal di wilayahnya. Namun, ia menyebarkan matamata dan polisi rahasia untuk mengawasi pergerakan Nabi Ibrahim, serta sedapat mungkin menjauhkan Nabi Ibrahim dari rakyatnya agar tidak terpengaruh. Raja

\footnotetext{
52 Kemenag, "Qur'an Kemenag," a. QS. Al-Baqarah:258.
}

53 Katsir, Kisah Para Nabi dan Rasul, 204-5. 
menunggu momentum yang tepat untuk memberikan pukulan yang telak kepada Nabi Ibrahim, karena ia telah menjadi ancaman yang nyata bagi kerajaannya. ${ }^{54}$ Sekalipun situasi sulit, menghadapi pasar dakwah yang kukuh memegang tradisi, dan penguasa yang selalu memberikan tekanan, tidak membuat Nabi Ibrahim berhenti untuk berdakwah. Beliau tidak mengeluh, melainkan terus menghadapi itu semua, dan tetap menyampaikan risalahNya kepada masyarakatnya.

Kelima, hijrahnya Nabi Ibrahim. Lamakelamaan pengawasan dan tekanan dari Raja Namrud melalui mata-mata dan polisi rahasianya semakin meningkat. Masyarakat yang sudah berhasil didakwahi Nabi Ibrahim terus dinetralisir oleh agen-agen dari Raja Namrud, sehingga mereka kemudian tidak mau lagi menerima dakwahnya Nabi Ibrahim. Padahal tanpa tindakan netralisir tersebut dakwah di masyarakat Babilonia sudah sangat sulit karena mereka demikian kuat mengikuti kepercayaan leluhurnya. Nabi Ibrahim kemudian sampai pada kesimpulan bahwa tidak ada gunanya untuk tinggal lebih lama di wilayah tersebut, karena hati penduduknya kebanyakan sudah tertutup rapat dengan kebodohan dan ajaran setan. ${ }^{55} \mathrm{Nabi}$ Ibrahim akhirnya memutuskan untuk hijrah, meninggalkan tanah airnya mencari lahan dakwah baru. Saat itu yang menyertainya hijrah adalah istrinya, Sarah, dan keponakannya, Luth bin Haran yang juga menjadi salah satu nabiNya. Dalam QS. Al-Ankabut ayat 26 disebutkian, "Maka Luth membenarkan (kenabian)nya. dan berkatalah Ibrahim: "Sesungguhnya aku akan berpindah ke (tempat yang

\footnotetext{
${ }^{54}$ Al-Warisyi, Dakwah Illahiah - Jalan Dakwah Tujuh Rasul Allah dalam Memperbaiki Masyarakat Jahiliyah, 230.
}

diperintahkan) Tuhanku (kepadaku); Sesungguhnya Dialah yang Maha Perkasa lagi Maha Bijaksana." 56

Daerah yang dituju dalam hijrah tersebut adalah wilayah Syam. Nabi Ibrahim berdakwah kepada penduduk yang menyembah bintang, tapi yang disampaikannya tidak mendapatkan respon positif. Selanjutnya, Nabi Ibrahim pergi ke daerah Yaman, yang ternyata sedang mengalami kemarau Panjang dan musibah kelaparan. Lantas Nabi Ibrahim pergi ke wilayah Mesir. Di Mesir, Nabi Ibrahim mendapatkan tekanan dari Raja Mesir. Ketika itu sang Raja bahkan tertarik dengan Sarah, istri Nabi Ibrahim. Dengan siasat dan pertolongan Allah, Nabi Ibrahim dan Sarah berhasil mengatasi tipu daya Raja Mesir, yang bahkan kemudian menghadiahkan seorang pelayan yang bernam Hajar kepada Sarah. Rombongan Nabi Ibrahim kemudian menuju daerah At-tayamun yaitu di sekitar Baitul Maqdis, Palestina. ${ }^{57}$

Keenam. Ujian perintah menyembelih putranya. Nabi Ibrahim dan keluarganya telah menetap di daerah Baitul Maqdis selama dua puluh tahun, namun selama itu pula belum dikaruniai seorang anak. Sarah kemudian menganjurkan Nabi Ibrahim agar menikahi pelayannya, Hajar. Tidak lama kemudian Hajar mengandung dan melahirkan seorang putra yang kemudian diberi nama Ismail. Nabi Ibrahim lantas membawa Hajar dan Ismail yang masih bayi ke pegunungan Faran yaitu tanah Mekkah. Ibrahim meninggalkan keduanya dan berdoa kepada Allah agar mereka dan keturunanya kelak diberi kemudahan dan tetap

\footnotetext{
55 Ibid., 230-31.

56 Kemenag, “Qur’an Kemenag," a. QS. Al-Ankabaut:26.

57 Katsir, Kisah Para Nabi dan Rasul, 205-12.
} 
mendirikan salat. Berkat pertolongan Allah, hajar dan Ismail bisa selamat dan hidup di wilayah tersebut. Tatkala Ismail sudah memasuki usia remaja, Nabi Ibrahim melalui mimpinya diperintahkan oleh Allah untuk menyembelih putra tercintanya tersebut. ${ }^{58}$ Sungguh ini merupakan ujian yang nyata dari Allah bagi Nabi Ibrahim. Padahal Ismail saat itu adalah putra satu-satunya yang telah lama dinantikan dan begitu dicintainya.

Mendapatkan mimpi tersebut, Nabi Ibrahim awalnya ragu. Sampai tiga kali mimpi tersebut Nabi Ibrahim kemudian memastikan bahwa itu adalah perintah dari Allah. Nabi Ibrahim pun menyampaikan kepada Ismail perihal mimpi tersebut. Sebagaimana diceritakan dalam QS. AsSaffat: 102, Maka ketika anak itu sampai (pada umur) sanggup berusaha bersamanya, (Ibrahim) berkata, "Wahai anakku! Sesungguhnya aku bermimpi bahwa aku menyembelihmu. Maka pikirkanlah bagaimana pendapatmu!" Dia (Ismail) menjawab, "Wahai ayahku! Lakukanlah apa yang diperintahkan (Allah) kepadamu; insya Allah engkau akan mendapatiku termasuk orang yang sabar." Jawaban dari Ismail tersebut menggambarkan puncak katenangan dan ketaatan kepada Allah dan orang tuanya. ${ }^{59}$

Dengan niat yang kuat, Nabi Ibrahim dan putanya, Ismail, berserah diri kepada Allah untuk melaksanakan perintah tersebut. Maka terjadilah peristiwa penyembelihan tersebut, dan Allah Swt. menunjukkan kuasaNya mengganti Ismail dengan seekor domba. Dikisahkan dalam QS. As-Saffat: 103107, Maka ketika keduanya (Nabi Ibrahim

58 Ibid., 216-20 dan 222-31.

59 Ibid., 225-26. dan Ismail) telah berserah diri dan dia (Ibrahim) membaringkan anaknya atas pelipis(nya), (untuk melaksanakan perintah Allah). Lalu Kami panggil dia, "Wahai Ibrahim! sungguh, engkau telah membenarkan mimpi itu." Sungguh, demikianlah Kami memberi balasan kepada orang-orang yang berbuat baik. Sesungguhnya ini benar-benar suatu ujian yang nyata. Dan Kami tebus anak itu dengan seekor sembelihan yang besar. ${ }^{\prime 60}$ Begitu luar biasa kemampuan dan energi spiritual yang dimiliki Nabi Ibrahim sehingga dia berhasil melaksanakan perintah yang maha berat tersebut dengan baik, dan Allah pun memujinya sebagai kekasihNya (Khalilullah) sebagaimana disebut dalam QS. An-Nisa' ayat 125, ... Dan Allah mengambil Ibrahim menjadi kesayanganNya.

\section{Pengelolaan Energi Spiritual Nabi Ibrahim sebagai Dai}

Dari peristiwa perjalanan Nabi Ibrahim sebagai dai sebagaimana di atas, akan dianalisis berdasarkan konsep manajemen energi spiritual. Prinsip dasar dari manajemen energi spiritual adalah membangun dan meningkatkan kapasitas energi spiritual secara bertahap, menggunakannya secara seimbang dan efisien, serta sistem pemulihan energi yang baik.

Perjalanan dakwah Nabi Ibrahim sangatlah berliku. Ada banyak tantangan yang dihadapi mulai dari ayahnya, masyarakatnya, penguasa/raja, sampai harus menghadapi atau melawan kecintaan terhadap putranya. Sebagai seorang dai sekalipun secara hasil

${ }^{60}$ Kemenag, "Qur'an Kemenag," a. QS. As-Saffat:102107. 
mitra dakwah yang disadarkan tidaklah banyak, namun ditinjau dari misi tauhid yang diembannya, Nabi Ibrahim dapat dikatakan sangat berhasil, bahkan menjadi teladan sepanjang masa. Oleh karenanya beliau diberi gelar oleh Allah sebagai Khalilullah atau kekasih Allah. Sebagaimana dijelaskan oleh AI-Warisyi bahwa ukuran keberhasilan dakwah tidak dilihat dari hasil sejauhmana mitra dakwah yang mengikuti, tetapi bagaimana etis jalan dakwah Illahiah dapat ditegakkan, yaitu tidak dengan segala cara, melainkan pelakunya (rasul dan pengikutnya) mempercayai kebenaran konsep Tauhid dan melaksanakannya pada kehidupan masyarakat, tidak boleh mengikuti jalan hidup orang-orang musyrik, kafir, dan yang mengikuti hawa nafsunya. Selain itu dakwah bersifat sekedar menyampaikan amanat, tidak memaksa, dengan tujuan agar mereka (mitra dakwah) dapat memperbaiki kekeliruannya dan mengikuti jalan yang benar. ${ }^{61} \mathrm{Nabi}$ Ibrahim sebagai seorang dai berhasil melaksanakan etis dakwah Illahiah tersebut.

Di balik keberhasilan Nabi Ibrahim dalam mengemban misi tauhid dan melaksanakan perintah-perintah-Nya terdapat kemampuan mengelola energi spiritual yang baik, sehingga dapat melewati keseluruhan tantangan-tantangan dakwah yang dihadapinya. Pokok-pokok pengelolaan energi spiritual Nabi Ibrahim terdiri atas: (a) pembangunan energi spiritual, yang dalam peristiwa di atas dilakukan melalui proses pencarian panjang dengan rasionalitasnya terhadap kebenaran Tuhan oleh Nabi Ibrahim; (b) peningkatan kapasitas energi spiritual secara bertahap melalui

\footnotetext{
${ }^{61}$ Al-Warisyi, Dakwah Illahiah - Jalan Dakwah Tujuh Rasul Allah dalam Memperbaiki Masyarakat Jahiliyah, 5-6.
}

pelaksanaan perintah Tuhan, berani mengambil resiko, menghadapi berbagai kesulitan dalam menyampaikan dakwah, dan mendapatkan berbagai rahmat dan pertolongan Allah; (c) menggunakan energi spiritual secara seimbang dan efisien, dengan tidak sedih berlarut-larut ketika mendapati kegagalan, melainkan memaknainya dengan bersyukur dan berdoa; (d) melakukan pemulihan energi spiritual secara seimbang, dengan menghayati kebenaran yang diyakini dan dilaksanakannya. Keempat prinsip itulah yang akan diuraikan lebih lanjut.

Jika diperhatikan pada awal perjalanan dakwahnya, Nabi Ibrahim dalam membangun landasan spiritualnya tidak dilakukan secara asal, melainkan melalui pencarian dan pembuktian secara ilmiah sebagimana dijelaskan di atas. Hal tersebut, menggambarkan bagaimana kemampuan menghayati, berpikir, serta merasakan secara mendalam terhadap fenomena penciptaan, kebesaran, dan kasih saying Allah. Ibaratnya Nabi Ibrahim seperti melakukan riset secara langsung siapakah Tuhan yang sebenarnya? Awalnya Nabi Ibrahim menduga Tuhannya adalah bintang, bulan, dan matahari. Namun kemudian dengan rasionalitasnya, Nabi Ibrahim menyadari bahwa Tuhannya adalah di balik semua itu, yang menciptakan dan mengatur semua yang ada di alam. Kemampuan rasionalitas yang didukung dengan cita rasa yang tinggi itulah yang kemudian mengantarkan Nabi Ibrahim untuk memiliki energi spiritual yang terus menerus bisa meningkat kapasitasnya. Dengan pemahaman yang ilmiah, Nabi Ibrahim 
memiliki kepercayaan yang kokoh terhadap keberadaan Tuhan, Zat Yang Maha Agung yang menjadi sumber nilai-nilai spiritual yang dia perjuangkan dalam hidupnya. Hal itulah yang menjadi nilai-nilai dan tujuan besar dalam hidupnya. Sebuah tujuan yang selalu dia letakkan di atas kepentingan pribadinya, yang menjadi basis energi spiritualnya.

Ketika Nabi Ibrahim mulai berdakwah, dengan pertama kali mendakwahkan tauhid kepada bapaknya, Nabi Ibrahim secara bertahap meningkatkan karakter keberanian dan kesediaan untuk menderita atau berkorban demi tujuan dakwahnya. Karakter-karakter tersebut adalah otot-otot yang harus dilatih untuk meningkatkan kapasitas energi spiritual. Dibutuhkan keberanian untuk menegur dan menasehati kesesatan bapaknya dalam menyembah berhala. Sekalipun Nabi Ibrahim telah menyampaikannya dengan lemah lembut, namun ternyata penolakan bapaknya demikian keras, menngancam rajam, dan mengusir Nabi Ibrahim. Hal ini, tentu menjadi tekanan emosi, mental, dan spiritual sekaligus bagi Nabi Ibrahim. Tekanan tersebut direspon dengan sangat baik oleh Nabi Ibrahim, dia tidak takut terhadap ancaman tersebut. Ketika diusir pergi, dia menerimanya. Padahal disitu ada kepentingan pribadinya yang terancam, yaitu kehilangan kasih sayang dari bapaknya, mungkin juga kehilangan hak waris dari keluarganyaa. Nabi Ibrahim menyadari, bahwa bagaimanapun Allah di atas segalagalanya. Itulah yang menjadi nilai-nilai utamanya. Nabi Ibrahim juga memahami bahkan bisa merasakan betapa sanksi dari Allah jauh lebih keras apabila dia tidak taat, dan malah mengikuti tindakan bapaknya.
Menghadapi masyarakatnya yang begitu kuat dalam penyembahan berhala, sehingga sampai Nabi Ibrahim menggunakan pendekatan empiris untuk membuktikan kesesatannya. Sekalipun demikian masyarakatnya banyak yang menolaknya, dimana-mana Nabi Ibrahim dihina dijadikan bahan gunjingan sebagai perusak tradisi leluhur. Sampai akhirnya Nabi Ibrahim disanksi dengan dibakar hidup-hidup. Luar biasanya hal tersebut tidak membuat Nabi Ibrahim ciut nyalinya. Dengan keberanian dan kesediaan berkorban, beliau menghadapi situasi tersebut. Nabi Ibrahim dengan landasan keimanan yang kuat, sangat percaya bahwa cukup Allah yang menjadi pelindungnya. Allah adalah nilai tertingginya, yang untuk itu nyawa pun siap dikorbankan. Dan Allah pula lah yang secara nyata memberikan pertolonganNya kepada Nabi Ibrahim saat dibakar kaumnya. Pengalaman tersebut semakin meningkatkan kapasitas energi spiritual Nabi Ibrahim, karena otot-otot spiritualnya yang berhubungan dengan karakter keberanian, pengorbanan, selalu terhubung dengan nilainilai tertingginya terus terlatih. Terlebih Allah kemudian menolongnya, maka bertambah kuatlah kepercayaan Nabi Ibrahim. Peningkatan kepercayaan terhadap sesuatu yang transenden berarti peningkatan kapasitas energi spiritual yang dimilikinya.

Ketika Nabi Ibrahim mengambil risiko untuk mendakwahi Raja Namrud. Raja yang zalim tersebut, sampai-sampai tidak bisa berkatakata karena kalah dalam berargumentasi tentang ajaran tauhid yang disampaikan oleh Nabi Ibrahim. Raja Namrud menjadi benci dan terus mengawasi, serta mempersempit ruang dakwah Nabi Ibrahim. Dimana-mana Nabi Ibrahim berdakwah selalu diikuti oleh 
mata-mata dan polisi rahasia dari kerajaan. Situasi dakwah semakin suit, namun Nabi Ibrahim tidak gentar dan terus berupaya secara konsisten untuk mendakwahkan tauhid di masyarakatnya.

Ketika lahan dakwah benar-benar tandus, Nabi Ibrahim melakukan evaluasi dan sampai pada kesimpulan bahwa masyarakat Babilonia sudah sangat sulit untuk didakwahi. Terlebih posisinya semakin terancam oleh Raja Namrud. Untuk itulah kemudian diputuskan berhijrah. Bukan hal mudah untuk melaksanakan hijrah, sebab ia harus meninggalkan tanah airya, segala harta, dan keluarga lainnya. Terlebih di tempat yang baru juga tidak ada jaminan akan keberhasilan dan keselamatan. Namun, berdiam diri di lahan yang tandus untuk berdakwah juga bukan pilihan yang bijak. Setidaknya di tempat yang baru, Nabi Ibrahim lebih leluasa untuk berdakwah. Melalui peristiwa dan pengalaman hijrah tersebut meningkatkan kapasitas keberanian kesediaannya untuk berkorban. Apalagi hijrah yang dilakukan Nabi Ibrahim tidak hanya berpindah langsung ke satu tempat, tetapi ke beberapa tempat, mulai dari wilayah Syam, Yaman, Mesir, sampai terakhir di sekitar Baitul Maqdis. Keberanian dan pengorbanan yang dilakukan Nabi Ibrahim menjadi pengalaman yang bisa meningkatkan kepasitasnya dalam mewujudkan nilai-nilai yang menjadi kepercayaannya.

Setelah Nabi Ibrahim sekian lama belum memiliki keturunan, dan akhirnya berhasil mendapatkan putra pertamanya, Ismail, kemudian turunlah perintah Tuhan untuk menyembelih putranya tersebut. Nabi Ibrahim yang kaya dengan pengalaman, rasionalitas, dan penghayatan yang mendalam akan kebesaran serta kasih sayang Allah, yang didapatkannya dalam banyak peristiwa. Di antaranya dalam Allah memberikan petunjuk akan keberadaanNya melalui tanda-tanda yang ada di alam, pertolongan Allah kepada Nabi Ibrahim saat dibakar dengan merubah sifat api menjadi dingin, pertolongan kepada keluarganya Hajar dan Ismail saat ditinggal di lembah Mekkah, dan sebagainya. Terhadap kaumnya yang mencoba membunuh utusannya, yaitu membakar Nabi Ibrahim, Allah juga tidak menghancurkannya. Berbagai peristiwa dan pengalaman keberanian, pengorbanan, ikatannya yang kuat dengan Zat yang Transenden menjadikan kapasitas energi spiritual Nabi Ibrahim terus meningkat.

Maka ketika Allah memerintahkannya untuk menyembelih putra tercintanya, Langkah awal yang dilakukan Nabi Ibrahim adalah memastikan bahwa perintah tersebut benar dari Allah. Tiga kali mimpi perintah tersebut hadir, sehingga Nabi Ibrahim sampai pada kesimpulan bahwa itu benar dari Allah. Kemudian Nabi Ibrahim menyampaikan perihal perintah tersebut kepada putranya, Ismail. Dari situ Nabi Ibrahim sekali lagi mendapatkan sokongan spiritual yang luar biasa, Allah ternyata mengabulkan doanya agar dikaruniai anak yang saleh. Jawaban dari Ismail yang meyakinkan ayahnya agar segera melaksanakan perintah tersebut menambah kapasitas energi spiritualnya. Seandainya perintah menyembelih putranya tersebut turun di masa awal kenabian Ibrahim, bisa jadi beliau akan kesulitan menjalankannya, karena kapasitas energi spiritualnya belum terlatih untuk menghadapi perintah yang maha berat. Namun, setelah Nabi Ibrahim berlatih terusmenerus melalui berbagai perintah dan 
menghadapi tantangan dakwah, kapasitas energi spiritualnya meningkat, sehingga menjadi lebih mungkin melakukannya. Dilaksanakanlah perintah tersebut dengan kemantapan, keberanian, dan kesediaan untuk mengorbankan putra yang sangat didambakan dan dicintainya. Menempatkan kepentingan pribadinya di atas Allah yang menjadi tempat tertinggi. Dan Allah pun membenarkan keduanya, seraya menyelamatkan Ismail dan menggantinya dengan sembelihan yang besar. Peristiwa dan pengalaman yang luar biasa tersebut membuat pemahaman dan pemikiran Ketauhidan Nabi Ibrahim semakin mendalam, karena sekali lagi Allah telah menunjukkan kekuasaan dan kasih sayangnya. Perasaan cinta Nabi Ibrahim kepada Tuhannya juga makin kuat. Demikian pula, keteguhannya untuk menempatkan Allah di atas segalanya dan konsisten melaksanakan perintah-perintahNya. Oleh karena itu, kapasitas energi spiritual Nabi Ibrahim terus meningkat, karena mampu melaksanakan perintah yang luar biasa tersebut.

Dari analisis di atas, dapat disimpulkan bahwa dalam mengelola energi spiritualnya, Nabi Ibrahim secara berkala dan kontinu meningkatkan kapasitas energi spiritualnya. Nabi Ibrahim terus melatih otot-otot spiritualitasnya, dengan karakter keberanian, kesediaan berkorban, tidak hanya mengorbankan dirinya tetapi juga putra yang sangat dicintainya. Semuanya dilakukan demi menempatkan Allah di atas segalanya. Semuanya dilakukan secara bertahap dan kontinu, sehingga otot-otot spiritualnya mendapatkan tekanan yang terukur dan waktu pemulihan memadai, sehingga dalam melatih otot-otot spiritualnya Nabi Ibrahim senantiasa melampaui zona nyaman spiritualnya. Hal tersebut membuat oto-otot spiritualnya tumbuh dengan baik dan memiliki kapasitas energi yang besar.

Selain meningkatkan kapasitas energi spiritualnya dengan baik, dalam penggunaan energi spiritualnya Nabi Ibrahim tidak boros. Artinya Nabi Ibrahim mampu menggunakan energi spiritualnya secara efisien dan seimbang. Hal tersebut ditunjukkan dengan, pertama, Nabi Ibrahim lebih banyak menggunakan energi yang bersifat positif, yaitu dengan keyakinan dan rasa cinta yang tinggi terhadap Tuhannya dan umatnya sebagai landasan untuk melaksanakan dakwah. Kedua, dengan energi positif tersebut Nabi Ibrahim siap menerima segala konsekuensi dari tugas dakwahnya, termasuk ketika dia diusir bapaknya, dicaci maki masyarakatnya, diintimidasi, bahkan sampai dibakar hidup-hidup. Ketiga, terhadap mereka yang telah membenci dan mengusirnya, seperti Tarekh, bapaknya Nabi Ibrahim, beliau tidak membencinya melainkan justru mendoakan keselamatannya. Keempat, energi spiritualnya tidak dihabiskan untuk meratapi situasi dakwahnya yang sulit. Energi spiritualnya tidak digunakan untuk bersedih hingga berlarut-larut ketika ditolak oleh bapaknya maupun dimaki dan diancam umatnya. Kelima, sekalipun sikap umatnya tidak tahu diri, padahal Nabi Ibrahim sudah memberikan bukti yang sangat empiris akan kesesatan penyembahan berhala, bahkan malah menghukum dengan membakar Nabi Ibrahim, tetapi Nabi Ibrahim merespons hal tersebut dengan ikhlas, menerimanya sebagai konsekuensi, serta tetap mendoakan mereka. Bersyukur Allah kemudian menyelamatkan Nabi Ibrahim dengan menjadikan api tersebut dingin. 
Dalam kemampuan Nabi Ibrahim memulihkan energi spiritualnya, dilakukan dengan cara merenungi dan menghayati akan kebenaran perilakunya dalam berdakwah. Bahwa apa yang dilakukannya adalah aman, betul, baik, dan diridai Allah Swt. Sang Pencipta dan Penguasa alam semesta. Aman, betul, baik, dan diridai Allah maksudnya adalah bahwa tindakan-tindakan yang dilakukannya adalah didasarkan pada kebenaran, melaksanakan perintah Allah untuk mendakwahkan nilai-nilai tauhid di masyarakat. Sekalipun tindakannya menentang kebiasaan dan tradisi, berbeda dengan ayahnya, bahkan menantang penguasanya, bukan berarti itu tidak aman, keliru, dan salah. Tetapi justru Allah memberikan jaminan keamanan dan kebaikan terhadap keberanian dan pengorbanan yang telah dilakukan Nabi Ibrahim. Sehingga, dengan pengalaman yang demikian, memudahkan Nabi Ibrahim untuk memulihkan energi spiritualnya ketika menghadapi berbagai kesulitan dan tantangan dakwah. Nabi Ibrahim memiliki bekal landasan ilmiah dalam pengenalan Tuhan beserta kebesaran dan kasih sayangNya. Selain itu beliau juga memiliki cita rasa yang tinggi. Dengan berbagai peristiwa kesulitan dakwah yang dihadapi Nabi Ibrahim, dan bukti nyata pertolongan Allah kepadanya, menjadi masukanmasukan bagi Nabi Ibrahim untuk dapat memulihkan energi spiritualnya dengan baik.

Untuk menunjang hal di atas, Nabi Ibrahim senantiasa mencukupkan diri dan membatasi pengalaman-pengalaman dalam merasakan kenikmatan yang bersifat non Ketuhanan. Artinya terhadap kenikmatankenikmatan duniawi, Nabi Ibrahim menyadari dan mampu menempatkannya dengan baik, tidak berlebihan. Adanya keberanian dan kesediaan berkorban dalam menerima kesulitan-kesulitan ketika diusir bapaknya, diancam, disiksa, dibatasi dan diawasi oleh penguasa adalah indikasi dari bagaimana Nabi Ibrahim menempatkan kenikimatan duniawi. Selain itu keberaniaannya melakukan hijrah yang berarti meninggalkan tanah airnya, beserta harta yang dimiliki di daerah asalnya juga menjadi indikasi bagaimana beliau mampu menempatkan kenikmatan duniawi dengan seimbang. Hal tersebut berani dilakukan karena Nabi Ibrahim menyadari dan memiliki kenikmatan Ketuhanan yang lebih kuat dari pada selainnya.

Dalam merasakan kenikmatan dunia, Nabi Ibrahim tidak secara berlebihan, baik itu yang berhubungan dengan kenikmatan materi, keluarga, maupun jabatan. Pertama, kenikmatan material secara berlebihan. $\mathrm{Nabi}$ Ibrahim dengan kemampuan rasionalnya memahami substansi dari kenikmatan material yang itu sifatnya terbatas, ada kejenuhan, dan sementara, dan akan berhenti saat manusia mengalami kematian. Kedua, kenikmatan dalam keluarga. Nabi Ibrahim dengan pengalaman dan kemampuannya menyadari hakikat keluarga, yang tidak lain adalah sebagai sarana untuk membangun masyarakat yang baik dan regenerasi misi tauhid. Kenikmatan keluarga mestilah diarahkan dan ditempatkan dibawah kepentingan Tuhannya. Ketiga, kenikmatan kekuasaan secara berlebihan, Nabi Ibrahim memiliki pengalaman berhadapan dengan penguasa, dan memahami bahwa mereka yang berkuasa belum tentu memahami atau menerima ajaran tauhid. Oleh karenanya Nabi Ibrahim tidak tergiur sama sekali dengan kenikmatan kekuasaan. Beliau 
menyadari bahwa kekuasaan semestinya dijadikan sarana melaksanakan misi tauhid dan membangun masyarakat yang baik.

\section{Kesimpulan}

Berdasarkan hasil analisis di atas, maka dapat disimpulkan bahwa Nabi Ibrahim dalam mengelola energi spiritualnya untuk menghadapi dinamika tantangan dakwah adalah sebagai berikut, pertama, meningkatkan kapasitas energi spiritual secara berkala dan kontinu. Hal tersebut, dimulai dengan bagaimana Nabi Ibrahim menjalankan perintah dakwah atas dasar keyakinan yang rasional, menghadapi berbagai tantangan dakwah mulai dari keluarga, masyarakat, sampai penguasa. Kesulitan-kesulitan dakwah dihadapi dengan cara-cara yang rasional dan dengan penuh keberanian serta pengorbanan. Sampai Nabi Ibrahim mendapatkan pertolongan Allah secara langsung melalui mukjizatnya. Keseluruhan peristiwa tersebut memberikan makna dan meningkatkan kapasitas energi spiritualnya. Bahkan beliau berani keluar dari zona nyaman spiritualnya, untuk menghadapi lahan baru dakwah yang belum pasti keberhasilannya.

Kedua, menggunakan energi spiritualnya secara efisien. Energi spiritualnya tidak dihabiskan untuk larut dalam kesedihan akan sikap mitra dakwah yang menolaknya, atau bersikap marah dan mengutuk umatnya yang telah membakarnya, tetapi beliau mendoakan mereka yang menolaknya, baik itu keluarganya, masyarakat, maupun penguasa. Sehingga energi spiritualnya bisa dikelola secara efisien, tidak boros dan tidak mudah habis karena tersalurkan untuk emosi yang negatif, tetapi dengan menyalurkannya ke emosi yang positif, yaitu dengan mendoakan dan ikhlas menerima. Ketiga, Nabi Ibrahim melakukan pemulihan energi spiritual secara seimbang dengan menghayati kebenaran perilakunya, kebaikan, dan kasih saying Allah kepadanya. Serta fokus pada tujuan, dan memberikan makna utama bahkan satu-satunya adalah untuk Tuhan. Maka segala masalah akan tampak kecil di hadapan Tuhan. Dengan pengelolaan yang demikian, Nabi Ibrahim akhirnya bisa memiliki energi spiritual yang sangat memadai, sehingga beliau siap melaksanakan perintah Allah yang sangat berat dengan mengorbankan putranya yang sangat dicintai.

Dari sini, dapat diambil hikmah dan rekomendasi bagi pelaku dakwah saat ini, bahwa sangat penting untuk meningkatkan kapasitas energi spiritual secara bertahap dan kontinu, serta pemulihan energi yang seimbang. Apalagi tantangan dakwah yang kini kian luar biasa. Apabila seorang dai tidak memiliki energi spiritual yang mencukupi akan kesulitan menghadapi kesulitan, tantangan, dan godaan dakwah di era modern. Peningkatan kapasitas energi spiritual dapat dilakukan dengan membangun pondasi yang ilmiah dalam berdakwah, memunculkan sikap-sikap keberanian, keikhlasan, dan pengorbanan sebagai otot-otot energi spiritual. Selain itu juga penting untuk menggunakan energi spiritual secara efisien, tidak menghabiskan energi spiritual untuk bersedih dan marah terhadap kesulitan dakwah, melainkan disalurkan ke hal-hal positif seperti dengan berdoa, menghayati, dan sebagainya. Serta memosisikan secara seimbang akan kenikmatan-kenikmatan materi, popularitas, maupun gaya hidup yang menjadi godaan dai dewasa ini. Dengan bekal itu semua, seorang dai akan dapat mengelola energi 
spiritualnya dengan baik dan siap menghadapi berbagai tantangan dan godaan dakwah pada era modern.

\section{Bibliografi}

Al-Warisyi, Iskandar. Dakwah Illahiah - Jalan Dakwah Tujuh Rasul Allah dalam Memperbaiki Masyarakat Jahiliyah. Surabaya: Yayasan Al-Kahfi, 2002.

- - - . Pengantar Silabus Dakwah Terprogram. Surabaya: Yayasan Al-Kahfi, 2012.

Azis, Moh. Ali. Ilmu Dakwah: Edisi Revisi. Jakarta: Kencana, 2017.

Budiono, Tri Joyo. "Pola Argumentasi Dalam Metode Dakwah Mujadalah Nabi Ibrahim." INTELEKSIA-Jurnal Pengembangan Ilmu Dakwah 02, no. 01 (2020): 1-26. http://inteleksia.stidalhadid.ac.id/index.php/inteleksia/article/view/75/30.

Efferi, Adri. "Profesionalisasi Da'I Di Era Globalisasi." Jurnal Komunikasi Penyiaran Islam 1, no. 2 (2013): 91-120. doi:http://dx.doi.org/10.21043/at-tabsyir.v1i2.

Ginandjar, Ary. Emotional Spiritual Quotient. Jakarta: Arga Wijaya Persada, 2001.

Harianto, Yudi Asmara. "Memaksimalkan Kinerja Organisasi Dakwah Melalui Manajemen Energi." Jurnal Kajian dan Pengembangan Manajemen Dakwah 05, no. 02 (2015).

Iqbal, Muhammad. "Nilai dan Strategi Dakwah dalam Kisah Nabi Ibrahim 'Alaihissalam." STAIN Padangsidimpuan, 2010. http://etd.iain-padangsidimpuan.ac.id/5565/1/05 110 133.pdf.

Ismail, Ilyas, dan Prio Hotman. Filsafat Dakwah (Rekayasa Membangun Agama dan Peradaban Islam). Jakarta: Kencana, 2011.

Kamaluddin. “Kompetensi Da'i Profesional." Hikmah 02, no. 01 (2015): 104-24. http://repo.iain-padangsidimpuan.ac.id/265/1/Kamaluddin.pdf.

Katsir, Ibnu. Kisah Para Nabi dan Rasul. Jakarta: As-Sunnah, 2007.

Kayo, Khatib Pahlawan. Manajemen Dakwah dari Dakwah Konvensional menuju Dakwah Profesional. Jakarta: Amzah, 2007.

Kemenag, LPMQ. “Qur'an Kemenag," 2021. https://quran.kemenag.go.id/.

Loehr, Jim, dan Tony Schwartz. Terampil Mengelola Energi Bukan Waktu. Jakarta: Serambi, 2008.

Meisil, Meisil B. Wulur. "Problematika Dakwah di Indonesia." Jurnal Mimbar: Media Intelektual Muslim dan Bimbingan Rohani 2, no. 1 (2016): 105-21. doi:10.47435/mimbar.v2i1.274.

Nurhanjati, Maisarah. "Kisah Nabi Ibrahim di dalam Al-Quran: Suatu Kajian Semiotik." Tesis. UIN Syarif Hidayatullah, Jakarta, 2008. https://repository.uinjkt.ac.id/dspace/handle/123456789/28214.

Petchsawang, Pawinee, dan Dennis Duchon. "Measuring Workplace Spirituality in an Asian Context." Human Resource Development International 12, no. 04 (2009): 459-68. doi:https://doi.org/10.1080/13678860903135912.

Pradesa, Dedy, dan Yunda Presti Ardilla. "Komodifikasi dan efek eksternalitas program dakwahtainment islam itu indah." INTELEKSIA-Jurnal Pengembangan IImu Dakwah 02, no. 01 (2020): 81-106. http://inteleksia.stidalhadid.ac.id/index.php/inteleksia/article/view/85.

Ridla, M. Rosyid, Afif Rifa'i, dan Suisyanto. Pengantar Ilmu Dakwah: Sejarah, Perspektif, dan Ruang Lingkup. Metode Dakwah. Yogyakarta: Samudra Biru, 2017. http://digilib.uinsuka.ac.id/id/eprint/29320.

Syahidin. Pemberdayaan Umat Berbasis Masjid. Bandung: Alfabetha, 2003.

Zohar, Danah, dan Ian Marshal. SQ: Kecerdasan Spiritual. Bandung: Mizan, 2007. 